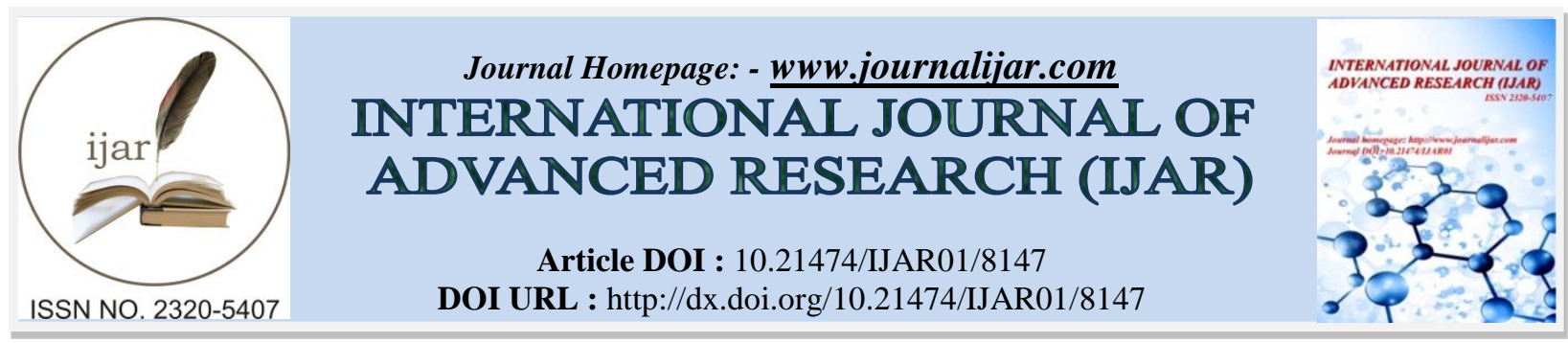

RESEARCH ARTICLE

\title{
DIVERSITY OF BACILLUS SPECIES AND THEIR ANTIMICROBIAL COMPOUNDS INVOLVED IN ALKALINE-FERMENTATION OF INDIGENOUS FOOD CONDIMENTS USED IN AFRICA.
}

Yérobessor Dabire $^{1,2}$, Marius K. Somda ${ }^{1}$, Jerry Ugwuanyi ${ }^{2}$, Lewis I. Ezeogu ${ }^{2}$ and Alfred S. Traore ${ }^{1}$.

1. Laboratory of Biotechnology in Food and Nutritional Sciences, Research Center in Biological Food and Nutritional Sciences, Department of Biochemistry and Microbiology, Research and Training Unit in Life and Earth Sciences, University Ouaga I, Prof. Joseph KI-ZERBO, 03 B.P 7031 Ougadougou 03, Burkina Faso.

2. Department of Microbiology, Faculty of Biological Sciences, University of Nigeria Nsukka, 410001, Enugu state, Nigeria.

\section{Manuscript Info}

\section{Manuscript History}

Received: 04 October 2018

Final Accepted: 06 November 2018

Published: December 2018

\section{Keywords:}

Alkaline-fermentation, indigenous food condiment, Bacillus spp., bioactive molecules.

\section{Abstract}

The indigenous food condiments, produced by alkaline fermentation of various African plant products, are widely used as food seasonings by most African people. Many strains of Bacillus genus are recognized as dominant microorganisms responsible of bioconversion of diverse plant-based seeds for the production of African alkaline-fermented food condiments. The involved Bacillus strains are known to produce a wide arsenal of useful antimicrobial compounds, particular polypeptides, lipopeptides and bacteriocins that exert broader spectra activities against Gram-negative and Gram-positive bacteria and fungi implicated in food toxicity or spoilage and ultimately human pathogenicity. Lipopeptides and bacteriocins present diverse biochemical structures with different mode and mechanism of action linked to their genetic and biosynthesis pathway. The molecular biology methods currently use in microbiological research allowed more reliable identification of antimicrobial polypeptides-producing Bacillus strains from these foods generating sufficient knowledge which potentiated the selection of starters cultures. The starters cultures and their antimicrobial peptides know a growing interest for effectiveness and best applications in many life domains. In this review, current knowledge about the main Bacillus species involved in African alkaline-fermented food condiments processes, mode and mechanism of action, genetic and biosynthesis pathway, and food applications of the antimicrobial peptides produced by these Bacillus strains are discussed.

Copy Right, IJAR, 2018, All rights reserved.

\section{Introduction:}

African indigenous food condiments are resulted products of alkaline fermentation of mainly various African plant seeds. They are prominent nutritional targets very rich in protein and ultimately serve as food flavoring agent and/or a low-cost protein source widely consumed in both rural and urban areas (Sanni et al., 2002; Taalé et al., 2015). These food condiments are very popular and also play an economic, social, cultural role among West Africa countries communities.

Corresponding Author: Yérobessor dabire.

Address: Laboratory of Biotechnology in Food and Nutritional Sciences, Research Center in Biological Food and Nutritional Sciences, Department of Biochemistry and Microbiology, Research and Training Unit in Life and Earth Sciences, University Ouaga I, Prof. Joseph KI-ZERBO, 03B.P 7031Ouagadougou 03, Burkina Faso. 
The processing of plant seeds to obtain each particular fermented food is usually a natural fermentation that produces biochemical and desirable changes in the final product through microbial hydrolysis activities.

Most studies, focused on isolation and identification of desirable microorganisms involved in the fermentation process for African fermented foods, have reached the general consensus that Bacillus species are the predominant bacteria both during the fermentation process and in the final product (Okorie and Olasupo, 2013a; Eze et al., 2014).

Members of Bacillus genus are phylogenetically included in class I of the phylum Firmicutes. The belong bacteria are Gram-positive, rod-shaped cell, aerobic or facultative anaerobic, catalase producer and ubiquitous in many environments. They possess the ability to form highly heat- and desiccation-resistant endospores. Phenotypically and genotypically heterogenous (Slepecky and Hemphill, 2006), Bacillus species exhibit quite diverse physiological properties, such as the ability to degrade many different substrates derived from animal and plant sources (Parkouda et al., 2009). In addition to chemoorganotrophy as metabolic characteristic, some Bacillus species are heterotrophic nitrifiers, denitrifiers, nitrogen fixers, iron precipitators, selenium oxidizers, manganese oxidizers and reducers, facultative chemolithotrophs, acidophiles, alkalophiles, psychrophiles, mesophiles, thermophiles, extremophiles and others (Slepecky and Hemphill, 2006).

The above characteristics of members of Bacillus genus includes to the growth requirements, allowed a diversity of Bacillus strains to colonize a wide variety of environments including soil, rocks, dust, aquatic milieu, vegetation, food and the gastro-intestinal tracts of various insects and animals (Nicholson, 2002).

Bacillus spores resist to heat, drying, disinfectants and other means of sterilization and this ability has a great relevance in food because of their economic concern in the food processing. Moreover, one of the main characteristics shared among members of the Bacillus group sensu lato is their recognition as good producers of a wide range of antimicrobial compounds, including polypeptides, lipopeptides and bacteriocins active against pathogenic and spoilage microorganisms (Stein, 2005; Compaoré et al., 2013a, b, c). The microbial control of these metabolites was demonstrated in plant environments, while with few studies realized on how these compounds can interact with food microbiota.

Due to their wide ubiquity in nature, their genetic and metabolic diversity, leading to sporulation capacity and several antimicrobial compounds production, Bacillus strains know an increasing interest for different biotechnological applications such as food industries in the fermentation process (Stein, 2005). Even though some Bacillus species or strains (Bacillus cereus, Bacillus coagulans, Bacillus thuringiensis, Bacillus weihenstephanensis, Bacillus subtilis, Bacillus licheniformis, Bacillus pumilus, Bacillus mycoides and Bacillus sphaericus) have been implicated in food toxicity and spoilage, well other species or strains (B. subtilis subsp subtilis, B. subtilis subsp natto, B. licheniformis, B. amylolichenfaciens, B. cereus) are nevertheless used in human and animal food production (Abriouel et al., 2011).

Therefore, the interspecies divergent virulence characteristics show that a rigorous selection process is required in the choice and development of Bacillus probiotic candidates or starters cultures (Barbosa et al., 2005; Hong et al., 2005). A single Bacillus strain can often produce several types of useful bioactive molecules, usually protein- and peptide-based compounds, stable over a wide range of $\mathrm{pH}$ and temperature and partially resistant to enzyme treatments (Abriouel et al., 2011). Interestly, Bacillus strains from alkaline-fermented foods condiments produce array antimicrobial compounds, particular lipopeptides and bacteriocins which exert a broad spectrum activity against Gram-negative and Gram-positive bacteria and fungi, which are human or animal pathogens (Savadogo et al., 2011; Compaoré et al., 2013a, b, c; Taalé et al., 2015).

Bacillus lipopeptides and bacteriocins present diverse biochemical structure, mode and mechanism of action linked to their genetic and biosynthesis pathways. According to their biosynthesis pathway, lipopeptides are synthesized enzymatically by large enzymatic complexes using non-ribosomal pathways, whereas bacteriocins are ribosomally synthesized peptides (Tapi et al. 2010).

The broader spectra of activity of Bacillus antimicrobial peptides led to suggest a possible application of these bacteria or their peptides (lipopeptides and bacteriocins) in food production and conservation. Food applications of Bacillus lipopeptides and bacteriocins are often limited due to many criteria such as the effectiveness inhibition of food pathogens, the 'Generality recognized as Safe' (GRAS) status and qualified presumption of safety (QSP) qualification, and the cost production very high (Abriouel et al., 2011). Nevertheless, many studies have shown a 
great growing interest to their effectiveness applications in food, biomedial and therapy, livestook and one others (Abriouel et al., 2011). In this paper, we are discussed on the mains Bacillus spp. involve in African indigenous alkaline-fermented food condiments production, the most known of their antimicrobial compounds, the mode and mechanism of action against foodborne or pathogen agents, the biosynthesis, and the potential applications of these antimicrobial compounds.

\section{Diversity of Bacillus species from African indigenous alkaline-fermented food condiments}

Alkaline food condiments are popular among most African countries. In addition to their important part in the diet (Parkouda et al., 2009), these food condiments play an economic, social and cultural role among African indigenous communities.

Several studies have focused on the microbiology diversity of alkaline fermented food condiments widely consumed by West African population. These studies generally reported Bacillus species as predominant microorganisms involved in the fermentation process of plant based-seeds for alkaline-fermented foods production (Parkouda et al., 2009). According to Omafuvbe et al. (2000), the alkaline fermentation is a process during which the $\mathrm{pH}$ of the substrate increases to alkaline values as high as $\mathrm{pH} 9$.

Dawadawa, produced from the seeds of African locus beans (Parki biglobosa), is very popular in West Africa and plays an important role in many diets (Terlabie et al., 2006, Savadogo et al., 2011). Dawadawa, common name in Nigeria and Ghana, is also known under different local names in west Africa such as iru in Nigeria (Sanni et al., 2000), soumbala in Burkina Faso (Savadogo et al., 2011), netetu in Senegal (Ndir et al., 1994), afitin, iru and sonru in Benin (Azokpota et al., 2006) and Kinda in Sierra Leone. The isolation and identification of microorganisms in dawadawa from different countries of West Africa have recorded Bacillus species as the main microorganisms with the predominance of with Bacillus subtilis (Parkouda et al., 2009; Savadogo et al., 2011). B. subtilis, B. licheniformis and B. pumilus have mainly been found in dawadawa with predominance of B. subtilis (Odunfa and Oyewole, 1986; Terlabie et al., 2006). Ndir et al. (1994) reported Bacillus species as dominant microorganism in Senegalese netetu. Sarkar et al. (2002) recorded the predominance of B. subtilis in soumbala of Burkina Faso. Ouoba et al. (2004) also confirmed the predominance of B. subtilis and even B. pumilus in soumbala, and then consider the long cooking period during soumbala production as main key step for the selection of heat-resistant spore-forming of Bacillus species (Ouoba et al., 2007b). Beninese afitin, iru and sonru, have found to hold Bacillus spp. (Azokpota et al., 2006).

Several Nigerian fermented food condiments are used as dishes flavor and/or a low-cost protein source (Sanni et al., 2002). Among others, we can cite, ugba from African oil bean (Pentaclethra macrophylla Bentham) seeds (Nurudeen et al., 2016); aisa from Albizia saman (Jacq.) F. Mull seeds (Ogunshe et al., 2006); okpehe, kpaye, or okpiye from mesquite (Prosopis Africana) seeds (Oguntoyinbo et al., 2007). Ogiri from melon (Citrullus vulgaris) seeds (Omafuvbe et al., 2004); and owoh from cotton (Gossypium hirsutum L.) seeds (Sanni and Ogbonna, 1991) are also listed in this group. All these food condiments have been investigated for their mean desirable microorganisms. The main fermenting microorganisms involved in the fermentation process of ugba were the proteolytic Bacillus species identified as B. subtilis (which is the most predominant), B. licheniformis, B. megaterium, B. macerans, and B. circulans (Nurudeen et al., 2016). Aisa has been found to harbor various Bacillus species as main microorganisms (Ogunshe et al., 2006). B. subtilis, B. licheniformis, B. megaterium, and B. pumilus were found as the main bacteria responsible for okpehe production (Ogunshe et al., 2007). B. pumilus, B. licheniformis, and B. subtilis are responsible of ground melon seeds fermentation for Ogiri production (Abaelu et al., 1990). Sanni and Ogbonna, (1991) reported the same species as dominant microorganisms in fermented cotton seeds, owoh.

Soydawadawa is made from soybeans (Glycine max L Merr) in Nigeria and Ghana (Omafuvbe et al., 2000; Terlabie et al., 2006). The Nigerian soydawadawa harbors mainly B. subtilis, B. licheniformis and B. pumilus (Omafuvbe et al., 2000), while B. cereus and B. firmis are furthermore found in the Ghanaian soydawadawa (Terlabie et al., 2006).

Bikalga also known as dawadawa-botso in Niger, datou in Mali, furundu in Sudan and muja in Cameroon, is one of the most popular condiments in Burkina Faso used to flavor many dishes (Compaoré et al., 2013a). It is produced from alkaline fermentation of Hibiscus sabdariffa L. commonly known as Roselle or sorrel (Ouoba et al., 2008 ). B. subtilis, B. licheniformis, B. cereus, B. pumilus, B. badius, B. sphaericus, B. fusiformis, and Brevibacillus 
bortelensis have been identified as the main microorganisms involved in bikalga production, with predominance of B. subtilis (Ouoba et al., 2008).

Maari is an alkaline-fermented food condiment processed by spontaneous fermentation of from Baobab (Adansonia digitata L.) seeds. It is consumed in a many West African countries, and has different names depending on ethnic tribe such as Dadawa Higgi or Issai in Nigeria, Dikouanyouri in Benin, N'Gono in Mali and Maari, Mackaari, Kaando, Thyou or Teed bikalgo in Burkina Faso (Parkouda et al., 2009). Parkouda et al. (2010) and Kaboré et al. (2012) reported the predominance of B. subtilis as mean microorganism isolated from Baobab fermenting seeds processed for Maari production in Burkina Faso.

Moreover, Bacillus species are also recognized as predominant microorganisms in Asian alkaline fermented food condiments (Wang and Fung, 1996). As good examples, we can cite B. subtilis in kinema (Sarkar et al., 2002) and thua-nao (Inatsu et al., 2006), Bacillus subtilis var. natto in natto (Wang and Fung, 1996), Bacillus amyloliquefaciens in Cheonggukjang and Doenjang (Hwang and Jeong, 2012), etc...

\section{Role of Bacillus species in alkaline fermentation of food condiments \\ Bioconversion of seeds during the fermentation}

During the fermentation process of African alkaline-fermented condiments, Bacillus species have found to provide the bioconversion of seeds components mainly proteins, lipids and carbohydrates leading to chemical and biochemical changes associated with the final products (Parkouda et al., 2009). The proteolysis has been found as the important biochemical changes that take place during the fermentation of plant-based products. During the process, the predominant bacteria, Bacillus species hydrolyze the proteins component of seed cotyledons to amino acids and ammonia (Ogunshe et al., 2007). Protease activity has been shown to rapidly increase from the start of the fermentation period till the end (Nurudeen et al., 2016).

Another biochemical change that has been shown to occur during the fermentation of various plant seeds is lipid hydrolysis. Bacillus species produced lipases that usually hydrolyze lipids to fatty acids (Terlabie et al., 2006). Free fatty acids levels generally increase during the plant-based products fermentation (Ogunshe et al., 2007), whereas decreasing concentration are recorded by Omafuvbe et al. (2004). These different results have been attributed to the predominance of different Bacillus spp. (such as B. subtilis and B. pumilus) that exerts high variable lipolytic activity during the fermentation process. (Ouoba et al., 2003a).

Plant seeds non-digestible carbohydrates (stachyose, raffinose, sucrose and arabinogalactan and verbascose) are also hydrolyzed into digestible sugars by several enzymes such as amylase, galactanase, galactosidase, glucosidase, and fructofuranosidase released by Bacillus species during the fermentation. These sugars influence positively the texture of the products (Terlabie et al., 2006; Ouoba et al., 2007a).

In addition, the rise in $\mathrm{pH}$ and the peculiar odor formation in the final products have been found and attributed to the abundant production of free amino acids and ammonia during the fermentation due to protein hydrolysis and deaminase activity. (Ouoba et al., 2003b; 2005). Indeed, the hydrolysis of plant seed components allows the production of flavor responsible of the pleasant taste, and important nutritional qualities of the fermented food condiments (Azokpota et al., 2008).

\section{Antimicrobial activity for fermented food safety.}

Strains of B. subtilis group exert potential antimicrobial effects against harmful bacteria and fungi and thus contribute to the stability and well-preservation of alkaline fermented food condiments (Savadogo et al., 2011; Compaoré et al., 20013a, b, c).

The soumbala isolated B. subtilis and B. pumilus strains exerted an antimicrobial effect against Gram-positive and Gram-negative bacteria such as Micrococcus luteus, Staphylococcus aureus, Bacillus cereus, Listeria monocytogenes, Escherichia coli, Salmonella typhimurium, Shigella dysenteriae, as well as ochratoxigenic moulds such as Aspergillus ochraceus (Ouoba et al., 2007b). Bacillus spp. strains of the same condiment have found to inhibit M. luteus (Taalé et al., 2015).

From soumbala and Bikalga, Savadogo et al. (2011) isolated both B. subtilis and B. licheniformis active against M. luteus LMG 3293, Aspergilus niger DSM 737, Penicillium roqueforti DSM 1080, Mucor rouxii DSM 1191 and Rhizopus orizae DSM 907. Pure cultures of B. subtilis subsp. subtilis, B. amyloliquefaciens ssp. Plantarum, and B. 
licheniformis strains isolated from Bikalga, have found to inhibit L. monocytogenes, M. luteus, S. aureus and B. cereus (Compaoré et al., 2013a, b, c).

\section{Antimicrobial peptides produced by Bacillus strains from alkaline - fermented food condiments}

Bacillus strains produced at least two dozen different antimicrobial compounds that allow them to compete with other microorganisms in the same environment (Stein, 2005). Bacillus subtilis was found to devote an important portion of its genome (average 4 to 5\%) for genes implicated in the production of antimicrobial compounds (Stein, 2005).

Predominant B. subtilis group species isolated from African indigenous alkaline-fermented food condiments have been demonstrated to produce antimicrobial compounds potent against foodborne pathogenic bacteria and fungi (Ouoba et al., 2007b; Savadogo et al., 2011; Compaoré et al., 2013a, b, c). The most important of these antimicrobial compounds are the peptides group including lipopeptides (iturins, fengycins, and surfactins) and bacteriocins and/or Bacteriocins Like-Inhibitrice Substances (BLIS) that exhibit often a broad specific spectrum of antimicrobial activity (Savadogo et al., 2011; Compaoré et al., 2013a, b; Taalé et al., 20015).

Using Polymerase Chain Reaction and Matrix Assisted Laser Desorption/ Ionization-Mass Spectrometry methods, Savadogo et al. (2011) identified surfactin from soumbala isolated Bacillus subtilis (S6, S21) strains.

The ultra-high-performance liquid chromatography-time of flight mass spectrometry analysis allowed Compaore et al. (2013a, b) to identify surfactin and fengycin as main antimicrobial substances produced by B. subtilis ssp. subtilis H4 and B. amyloliquefaciens ssp. Plantarum strains isolated from Bikalga. Taalé et al. (2015) recorded BLIS production by Bacillus spp. strains

Other antimicrobial compounds include polyketides (bacillaene, difficidin, and macrolactin), amino sugars and phospholipids (Stein, 2005).

\section{Classification of antimicrobial peptides produces by Bacillus species}

According to the biosynthesis pathways, the main antimicrobial peptides produced by Bacillus can be grouped in two dominant classes (Marx et al., 2001): the first group includes the non-ribosomally synthesized peptides, whereas the second comprises ribosomally synthesized peptides both presenting very diverse structures (Tapi et al., 2010).

\section{Non ribosomally synthesized peptides: The cyclic lipopeptides}

Bacillus species produce 3 groups of cyclic lipopeptides families namely surfactin, iturin and fengycin illustrated in fig. 1(Khem and shamsher, 2015).

\section{Iturin family}

With a molecular mass of $\sim 1.1 \mathrm{kDa}$, iturin is the smaller product among the 3 types of lipopeptides. The iturin family, including the related lipopeptides iturin A, C, D and E isoforms, bacillomycin D, F and L and mycosubtilin (Peypoux et al., 1986). All these compounds contain a cyclic heptapeptide composed of 7 amino acids interlinked or acylated with $ß$-amino fatty acids chain that can vary from C-14 to C-17 carbon atoms (Savadogo et al., 2011).

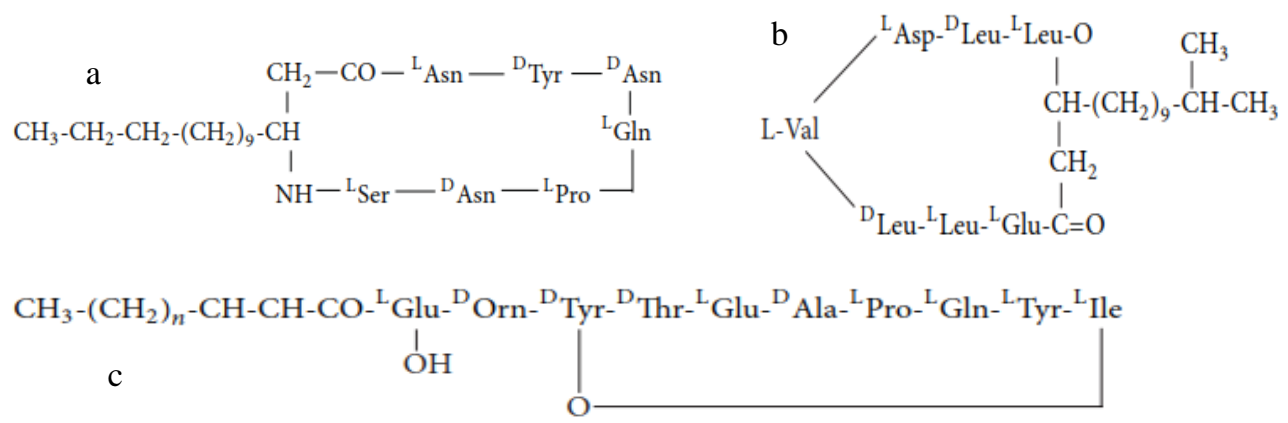

Figure 1:-(a) Cyclic structure of lipopeptide iturin, consisted of seven amino acid residues attached to a 14-carbon chain, indicates its amphiphilic nature. Three D-amino acids (Tyr, Asn, and Asn) and four L-amino acids (Pro, Ser, Asn, and Gln) are the amino acids involved in this structure. (b) The cyclic heptapeptide surfactin contains both hydrophobic and hydrophilic amino acids. The structure containing amino acids: two D-amino acids (Leu, Leu) and five L- amino acids (Val, Asp, Leu, Glu, and Leu), indicates its amphipathic nature. (c) Primary cyclic structure of fengycin A. Structure containing peptide chain of ten amino acids and a $\beta$-hydroxyfatty acid chain that can vary according to fengycin isomer from $\mathrm{C}-14$ to $\mathrm{C}-17$ carbons. In the structure, the amino acids are six L-amino acids 
(Glu, Glu, Pro, Gln, Tyr, and Ile) and four D-amino acids (Tyr, Orn, and Thr, Ala). Source: Khem and Shamsher, (2015).

Iturin A comprises two major parts: a heptapeptide part and a hydrophobic tail of 11 to12 carbons (Fig. 1(a)). This structure clearly shows an amphiphilic character of these compounds that targeted on the cellular membranes as the most probable site of their action (Aranda et al., 2005). Such molecules are of great interest because of their biological and physicochemical properties exploitable in food, oil, industry, etc... Source: Stein, 2005.

\section{Surfactin family}

The surfactin family contains a cyclic heptapeptide, with amino acids L or D, that form a lactone bridge with $B$ hydroxy $(\beta-\mathrm{OH})$ fatty acid. The $\beta$-hydroxy fatty acid carbon chain length of $\mathrm{C}-13$ to $\mathrm{C}-18$ with amino acids sequence completely different from iturins (Magnet-Dana et al., 1992).

Surfactin $(\sim 1.36 \mathrm{kDa})$ is an amphipathic cyclic lipoheptapeptide of Glu-Leu-Leu-Val-Asp-Leu-Leu (ELLVDLL) containing the chiral sequence LLDLLDL interlinked with $\beta$-hydroxy fatty acid chain consists of 12 to 16 carbon atoms to form a cyclic lactone ring structure (Fig. 1(b)) (Seydlová et al., 2011). Different types of surfactin can be obtained according to the order of amino acids and the size of lipid portion, (Korenblum et al., 2012). Surfactin molecule contains hydrophobic amino acids located at positions 2, 3, 4, 6 and 7, and Glu and Asp residues located at positions 1 and 5, respectively. Surfactin isoforms usually coexist in the cell as a mixture of several peptidic variants with a different aliphatic chain length (Savadogo et al., 2011). The pattern of amino acids and $\beta$-hydroxy fatty acids in the surfactin molecule depends both on producer bacterial strain and type of culture conditions (Seydlová et al., 2011). An intramolecular hydrogen bond can form the $\beta$-turn, whereas the $\beta$-sheet may depend on the same bond (Zou et al., 2010).

\section{Fengycin family}

Fengycin family includes cyclic lipodecapeptides formed by lactonization (Pathak et al., 2012). Fengycin structure consists of a saturated or unsaturated $\beta$-hydroxy fatty acid chain linked to the N-terminus of a cyclic decapeptide (Figure 1(c)) (Akpa et al., 2001). In the structure 8 amino acids (Tyr, Thr, Glu, Ala, Pro, Gln, Tyr, and Ile) of it decapeptide chain portion are involved in the formation of a peptide ring via lactone linkage between the side-chain phenolic-OH group of Tyr3 and C-terminal-COOH group of Ile10 (Pathak et al., 2012). Members of Fengycin family present heterogeneity both at the $6^{\text {th }}$ position in peptide moiety, and in $\beta$-hydroxy fatty acid chain length that ranges from $\mathrm{C}-14$ to $\mathrm{C}-17$ carbon atoms and allows to obtain different homologous compounds and isomers (Kim et al., 2004). According to the variation of single amino acid at the $6^{\text {th }}$ position in peptide ring, fengycins have been classified in two classes: Fengycin A and fengycin B. Fengycin A contains Ala at position 6 and harbor unusual amino acids such as ornithine, while Val substituted Ala in case of fengycin B which isoforms harbor an allothreonine (Wang et al., 2004).

\section{Bacteriocins and Bacteriocin-Like Inhibitory Substances (BLIS) Different classifications of Bacteriocins}

Bacillus species produced bacteriocins and BLIS considered as the second most important after Lactic Acid Bacteria (LAB) bacteriocins. The main classification scheme for bacteriocins currently available is that of the LAB bacteriocins (Cotter et al., 2013). The classification scheme of LAB bacteriocins, firstly established by Klaenhammer (1993), has known subsequently many adaptations or reclassifications proposed by several authors taking account the chemical structure, the presence of modified amino acids, the molecular mass, the heat stability, the enzymatic sensitivity, the biosynthesis mechanism, and the mode of action of these bacteriocins (Arnison et al., 2013). According to above, Alvarez-Sieiro et al. (2016) proposed three major classes of LAB bacteriocins: Class I harbors small post-translationally modified peptides, Class II contains unmodified bacteriocins, and Class III holds larger peptides (>10 kDa, thermo-labile).

Some antimicrobial peptides produced by Bacillus species have been included in the classes of LAB bacteriocins (as previously described by Klaenhammer, 1993). A good number of Bacillus bacteriocins belong to the group of lantibiotics (Bierbaum and Sahl, 2009) included in the class I of LAB bacteriocins classification scheme (Nes et al., 2007). Furthermore, several bacteriocins/BLIS produced by Bacillus species belong to class II of LAB bacteriocins including the class IIa-pediocin-like bacteriocins and the two-peptide bacteriocins (class IIb) (Nes et al., 2007). However, some Bacillus lantibiotics described like halodurancin, lichenicidin, sublancin 168 or paenibacillin do not fit clearly in any of the classes of lantibiotics described above (Abriouel et al., 2011). 
Given the new elucidation of the structure, mode of export and mechanism of action of different described bacteriocins fall in various groups of bacteria, a unifying classification scheme of all bacteriocins still quite very difficult to establish (Makhloufi, 2011). So that, Abriouel et al. (2011) have proposed a separated classification scheme of Bacillus bacteriocins independently to that of LAB bacteriocins.

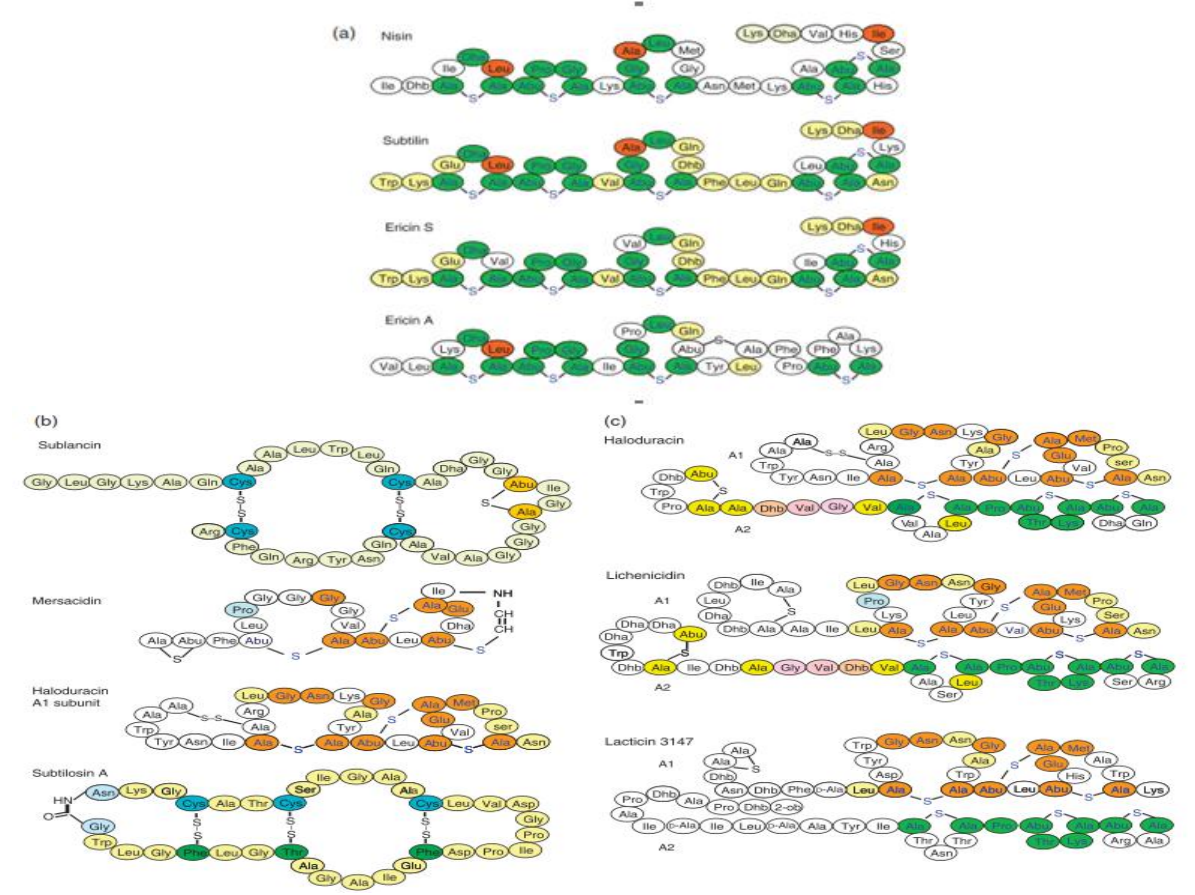

Figure. 2:-(a) St ructures of subtilin and ericin compared with that of the lactococcal lantibiotic nisin A. Nisin, subtilin, ericin $\mathrm{S}$ and A possess conserved residues at identical positions that are highlighted in green, while those conserved only in subtilin and ericins are depicted in yellow; other conserved residues are in light red. (b) Structures of the single-peptide lantibiotics sublancin, mersacidin and subtilosin A. The conserved residues from the comparison of A1 subunit of haloduracin and mersacidin structures are highlighted in orange. Cysteins involved in disulfide bridge formation are highlighted in blue. For subtilosin A, residues involved in sulfur to $\alpha$-carbon linkages are shown in green, while residues involved in head-to-tail amide bond formation are in light blue. (c) Comparison of the two-peptide lantibiotics haloduracin and lichenicidin from Bacillus, and lacticin 3147 from Lactococcus lactis. The highlighted orange and light yellow colors show the conserved residues of the A1 peptides. A conserved Pro residue between lichenicidin A1 subunit and mersacidin is shown in light blue. For A2 peptides, conserved residues are highlighted in green, deep yellow, light orange and violet. Two conserved loops of 11 and eight amino acid residues are also shared in the C-terminal parts of $\mathrm{A} 1$ subunits. The $\mathrm{C}$-terminal parts of $\mathrm{A} 2$ peptides share the same pattern of lanthionine (Ala-S-Ala) and methyllanthionine (Abu-S-Ala) bridges. The white bowls correspond to the non-identical residues. Source: Abriouel et al. (2011).

Hence, until to date, only their classification scheme for Bacillus bacteriocins is available. This fact is most probably due to the lack of information on many of these bacteriocin amino acids sequences, and genes cluster and the considerable diversity of the peptides/proteins produced by the bacilli. According to Abriouel et al. (2011), there are three classes of Bacillus bacteriocins: Class I includes the post-translational modified peptides, Class II harbors the small non-modified and linear peptides, and Class III regroups large proteins. Moreover, the antimicrobial polypeptides and large antimicrobial proteins, unclearly identify are described under the category of BLIS (Abriouel et al., 2011).

\section{The different classes of Bacillus bacteriocins}

All the different classes of bacteriocins produced by Bacillus isolates are summarized in the Table 1 according to the classification scheme of Abriouel et al. (2011)

\section{Class I bacteriocins}

Class I regroups all the thermo-resistant antimicrobial peptides that undergo post-translational modifications and often contain some unusual amino acids. They are four subclasses: Subclass I.1 named lantibiotics, Subclass I.2 
called other single-peptide lantibiotics, Subclass I.3 or two-peptide lantibiotics and Subclass I.4 includes other posttranslationally modified peptides.

\section{Subclass I.1: The lantibiotics}

This subclass (Table 1) includes type-A lantibiotics (2.1 to $3.5 \mathrm{kDa})$ that are modified by a dual-enzyme system generically referred to as LanBC. They consist of 21 to 38 amino acid residues, exhibit more linear secondary structure and target the Gram-positive bacteria through voltage-dependent pores formation into the cytoplasmic membrane (Abriouel et al., 2011). Type-A lantibiotics include subtilin, the paradigm lantibiotic extensively studied in terms of its protein structure and genetic determinants. Subtilin (Fig. 2a) is a $3.32 \mathrm{kDa}$ pentacyclic lantibiotic that contains 32-amino acid cationic, stable to acid and heat treatment up to $121^{\circ} \mathrm{C}$ for $30-60 \mathrm{~min}$, and inhibits a broad range of Gram-positive bacteria including other Bacillus species (Guder et al., 2000). It is structurally similar to nisin from Lactobacillus lactis (Gálvez et al., 2007), and to B. subtilis A 1/3 ericins (Stein et al., 2002a). Another variant of subtilin named subtilin B (3419.58 Da) is produced by B. subtilis ATCC 6633 (Stein, 2008).

Ericin A (2986 Da) and S (3442 Da) (Fig. 2a) are two related lantibiotics produced by B. subtilis A1/3 and strongly similar to subtilin (Stein et al., 2002a). The mature ericin S and A reveal highly similar properties even though their precursors show only $75 \%$ identity. Only four amino acid residues distinguish ericin S to subtilin (Fig. 2a). Ericin S contains a subtilin-like lanthionine-bridging pattern that makes its antimicrobial activity and physico-chemical properties similar to subtilin. Different ring organization and 16 amino acid substitutions are held by ericin A compared with ericin S (Fig. 2a). Ericin A differs to subtilin by two C-terminal rings from it lanthionine pattern (Stein et al., 2002a).

\section{Subclass I.2: the other single-peptide lantibiotics}

The subclass I.2 includes type-B lantibiotics mersacidin, sublancin 168 and paenibacillin (Table 1). The B. subtilis strain HIL Y-85.54728 mersacidin is a tetracyclic peptide with 1824 Da molecular mass (Bierbaum et al., 1995). Mersacidin displays a more globular structure due to the formation of four intermolecular thioether bridges or rings (Fig. 2b). Its four intramolecular rings are presented in two separate ones in the N-terminal part, and two intertwined ones without elongated linear stretches in the $\mathrm{C}$-terminal part. The presence of intertwined rings extends protease resistance in comparison with other Bacillus lantibiotics (Abriouel et al., 2011).

Sublancin 168 (Fig. 2b) is a chromosomally encoded lantibiotic co-produced with subtilosin A by a wild-type strain Bacillus subtilis 168 (Sutyak et al., 2008b). The sublancin 168 (3877.78 Da) structure consists of a single lanthionine linkage and two unusual disulfide bridges (Paik et al., 1998).

Paenibacillin produced by Paenibacillus polymyxa OSY-DF, possesses a N-terminal acetyl group (He et al., 2008).

\section{Subclass I.3: The two-peptide lantibiotics}

Haloduracin and lichenicidin (Table 1) are two-peptide lantibiotics produced by Bacillus species. They consisted of two ( $\beta$-methyl) lanthionine-containing peptides A1, and A2. The mature A1-peptides are similar to mersacidin with several fused thioether rings, whereas the mature A2-peptides are typically elongated and more flexible. The mature Hal $\alpha / \mathrm{A} 1$ and Hal $\beta / \mathrm{A} 2$ peptides (obtained through post-translational modification performs by enzymes HalM1 and HalM2) weighed 3046 and $2332 \mathrm{Da}$ molecular masses, respectively as showed the MALDI-TOF analysis (McClerren et al., 2006). These two-peptide lantibiotics are closely related to those of other bacteria such as plantaricin W of Lactobacillus plantarum (Holo et al., 2001).

Two Bacillus strains, B. licheniformis ATCC 14580 and B. licheniformis DSM 13 (Dischinger et al., 2009) produced lichenicidin (Fig. 2c) having higher homology to haloduracin of B. halodurans C-125 (Lawton et al., 2007). The A subunit of lichenicidin also shows homology to mersacidin (Bierbaum et al., 1995).

\section{Subclass I.4: The other post-translationally modified peptides}

The subclass I.4 holds the other post-translationally modified peptides. A good example is subtilosin A produced by B. subtilis ATCC 6633 and other B. subtilis strains, as well as B. amyloliquefaciens and B. atrophaeus strains (Sutyak et al., 2008b). Subtilolisin A was originally isolated from B. subtilis 168 by Babasaki et al. (1985) who gave its uncompleted amino acid sequence later completely published by Zheng et al. (1999). Subsequently, Marx et al. (2001) provided further elucidation of subtilosin A (Figure 2a) as a macrocyclic peptide. The mature subtilosin A consists of 35 amino-acid cyclized by an unusual amide bond between $\mathrm{N}$ - and $\mathrm{C}$ - termini of asparagine and glycine, respectively, and also contains three intramolecular bridges formed between the sulfurs of Cys13, Cys7 and Cys4 
and the $\alpha$-carbons of Phe22, Thr28 and Phe31, respectively (Marx et al., 2001; Sutyak et al., 2008b). Subtilosin A is an anionic molecule, with 3399.7 Da molecular mass (Marx et al., 2001), an acidic isoelectric point (Stein et al., 2004). It possesses high stability under extreme temperature and $\mathrm{pH}$ stresses, with full activity retained after an hour at $100^{\circ} \mathrm{C}$ or in the $\mathrm{pH}$ range of 2-10 (Sutyak et al., 2008b). The hemolytic mutant of B. subtilis produced a variant of subtilosin A called subtilosin A1(3412.5 Da), with substitution at $6^{\text {th }}$ position of threonine by isoleucine (Huang et al., 2009).

\section{Class II bacteriocins: Non-modified peptides}

This class forms a heterogeneous group of heat-stable, membrane-active peptides smaller than $10 \mathrm{kDa}$, that possess only standard amino acids and do not undergo post-translational modifications (Fernandez, 2014). They are subdivided in three subclasses: subclass II.1 named pediocin-like peptides, subclass II.2 or thuricin-like peptides, and subclass II.3 or linear peptides.

\section{Subclass II.1: The Pediocin-like peptides}

Bacillus Pediocin-Like peptides possess a disulfide bridge essential to the activity and a consensus motif YGNGVX1CX2K/NX3X4-C (X= any amino acid) at their N-terminal part. Their C-terminal portion is variable and can be both hydrophobic and hydrophilic (Feng et al., 2009). Coagulin (4612 Da) produced by B. coagulans I4, is an example of pediocin-like peptide, heat-stable and protease-sensitive, with anti-listeria activity (Table 1) (Le Marrec et al., 2000).

Paenibacillus polymyxa strains (NRRLB-30507, NRRLB-30508, and NRRLB-30509) as well as B. circulans strain NRRLB-30644 produced different anti-Campylobacter bacteriocins, with N-terminal sequences similar to LAB pediocin-like bacteriocins (Abriouel et al., 2011).

\section{Subclass II.2: The Thuricin-like peptides}

Members of thuricin-like peptides are characterized by their N-terminal consensus sequence (DWTXWSXL) and include several peptides described among B. thuringiensis strains as well as B. cereus MRX1 strain (Abriouel et al., 2011). We can cite Thuricin 17 of $\mathrm{B}$. thuringiensis NEB17. This peptide is protease-sensitive, temperature- $\left(100^{\circ} \mathrm{C}\right.$ for $15 \mathrm{~min}$ ) and $\mathrm{pH}$ - (1.5 to 9.0) resistant (Abriouel et al., 2011). Thuricin 17 (3160 Da) shares the same N-terminal sequence as Thurincin H (3139.51 Da) of B. thuringiensis SF361 (Lee et al., 2009a), Thuricin S (3137.61 Da) from B. thuringiensis ssp. entomocidus HD198 (Chehimi et al., 2007), Bacthuricin F4 (3160.05 Da) of B. thuringiensis ssp. kurstaki BUPM4 (Kamoun et al., 2009), and cerein MRX1 (3137.93 Da) of B. cereus MRX1(Table 1) (Sebei et al., 2007).

\section{Subclass II.3: The other linear peptides}

This subclass harbors linear peptides such as cerein 7A and cerein 7B. Cerein 7A initially called cerein 7, and cerein 7B are two non-synergistic bacteriocins produced simultaneously by Bacillus cereus Bc7 (CECT 5148) (Oscáriz et al., 2006). Cerein 7A and cerein 7B can be distinguished by their molecular masses (3940 Da and $4893 \mathrm{Da}$, respectively), and their N-terminal amino acid sequences, which are GWGDVL (7A) and GWWNSWGH (7B), respectively (Table 1) (Oscáriz et al., 2006).

\section{Class III: Large proteins}

Megacin A-216 and A-19213 produced by B. megaterium 216 and B. megaterium ATCC 19213, respectively, belong to the A-group megacins that exhibits phospholipase A2 activity implicated in the conversion of phospholipids to the corresponding lysophospholipids (Abriouel et al., 2011). With a native molecular weight of 66000 Da, megacin A-216 contains 293 amino acid residues. Three components designated as $\gamma, \alpha$, and $\beta$ chains (32855, 21018 and $11855 \mathrm{Da}$, respectively) corresponding to the full-length protein and two cleavage products correspond to its bioactive fraction (Table 1) (Kiss et al., 2008).

\section{Bacteriocin-Like peptides and Bacteriocin-Like Inhibitory Substances (BLIS).}

The antimicrobial peptides produced by Bacillus species, with either uncompleted genetic or amino acid characterization, are regrouped under the name of Bacteriocin-Like Peptides (BLP) or Bacteriocin-Like Inhibitory Substances (BLIS) (Abriouel et al., 2011). BLP are active against bacteria excepted yeast or fungi, while BLIS have either both antibacterial and antifungal activities or only antifungal activity and so that fall into the category of "antifungal compounds", The majority of these categories of antimicrobial peptides produced by different Bacillus 
species have previously been widely described by Abriouel et al. (2011) and their detailed description is beyond the scope of this review.

Table 1: Classification of bacteriocin produced by Bacillus species (Abriouel et al., 2011)

\begin{tabular}{|c|c|c|c|c|c|c|}
\hline Classes & Subclasses & Examples & $\begin{array}{l}\text { Producer } \\
\text { strains }\end{array}$ & $\begin{array}{l}\text { Molecular } \\
\text { weight(Da) }\end{array}$ & Special features & References \\
\hline \multirow{11}{*}{$\begin{array}{l}\text { Class I: Post- } \\
\text { translational- } \\
\text { ly modified } \\
\text { peptides }\end{array}$} & \multirow{4}{*}{$\begin{array}{l}\text { Subclass-I.1: } \\
\text { Single- } \\
\text { peptide, } \\
\text { elongated } \\
\text { lantibiotics }\end{array}$} & Subtilin & $\begin{array}{l}\text { Bacillus subtilis } \\
\text { group,B. subtilis }\end{array}$ & 3319.56 & $\begin{array}{l}\text { Type A-lantibiotic, } \\
\text { binds lipid II. }\end{array}$ & (Stein, 2008) \\
\hline & & Subtilin B & B. subtilis A1/3 & 3420 & $\begin{array}{l}\text { Type A-lantibiotic, } \\
\text { succinylated } \\
\text { subtilin, binds } \\
\text { lipid II. }\end{array}$ & (Stein, 2008) \\
\hline & & Ericin $\mathrm{S}$ & B. subtilis A1/3 & 3442 & $\begin{array}{l}\text { Type A-lantibiotic, } \\
\text { anti-Clavibacter. }\end{array}$ & $\begin{array}{l}\text { (Stein et al., } \\
\text { 2002a) }\end{array}$ \\
\hline & & Ericin A & B. subtilis A1/3 & 2986 & Type A-lantibiotic & $\begin{array}{l}\text { (Stein et al., } \\
2002 \mathrm{a})\end{array}$ \\
\hline & \multirow{3}{*}{$\begin{array}{l}\text { Subclass-I.2: } \\
\text { Other single- } \\
\text { peptide } \\
\text { lantibiotics } \\
\text { (globular), }\end{array}$} & Sublancin 168 & B. subtilis 168 & 3877.78 & $\begin{array}{l}\text { AII-lantibiotic, } \\
\text { Unusual } \\
\text { lantibiotic. }\end{array}$ & $\begin{array}{l}\text { (Paik et al., } \\
1998)\end{array}$ \\
\hline & & Mersacidin & \begin{tabular}{|lr} 
B. & subtilis \\
HILY-85.54728
\end{tabular} & 1824 & $\begin{array}{l}\text { Type B-lantibiotic } \\
\text { Tetracyclic, binds } \\
\text { lipid II. }\end{array}$ & $\begin{array}{l}\text { (Bierbaum et } \\
\text { al., 1995) }\end{array}$ \\
\hline & & Paenibacillin & $\begin{array}{l}\text { Paenibacillus } \\
\text { polymyxa OSY- } \\
\text { DF }\end{array}$ & 2983.5 & Type B-lantibiotic. & $\begin{array}{l}(\mathrm{He} \text { et al., } \\
2007)\end{array}$ \\
\hline & \multirow{2}{*}{$\begin{array}{l}\text { Subclass-I.3: } \\
\text { Two } \\
\text { component } \\
\text { lantibiotics }\end{array}$} & $\begin{array}{l}\text { Haloduracin } \\
(\mathrm{A} 1, \mathrm{~A} 2)\end{array}$ & $\begin{array}{l}\text { B. halodurans C- } \\
125\end{array}$ & $\begin{array}{c}3046 \text { and } \\
2332 \\
\end{array}$ & $\begin{array}{l}\text { Two-peptide } \\
\text { lantibiotic. }\end{array}$ & $\begin{array}{l}\text { (McClerren } \\
\text { et al., 2006) }\end{array}$ \\
\hline & & $\begin{array}{l}\text { Lichenicidin } \\
(\alpha, \beta)\end{array}$ & $\begin{array}{l}\text { B. licheniformis } \\
\text { ATCC } 14580 \\
\text { and DSM13 }\end{array}$ & $\begin{array}{l}3253.92 \\
\text { and } \\
3021.69\end{array}$ & $\begin{array}{l}\text { Two-peptide } \\
\text { lantibiotic. }\end{array}$ & $\begin{array}{l}\text { (Dischinger } \\
\text { et al., 2009) }\end{array}$ \\
\hline & \multirow{2}{*}{$\begin{array}{l}\text { SubclassI.4: } \\
\text { Other post- } \\
\text { translational- } \\
\text { ly modified } \\
\text { peptides }\end{array}$} & Subtilosin A & $\begin{array}{l}\text { B. subtilis } \\
\text { ATCC } 6633\end{array}$ & 3399.7 & $\begin{array}{l}\text { Macrocyclic } \\
\text { antibiotic. }\end{array}$ & $\begin{array}{l}\text { (Marx et al., } \\
\text { 2001) }\end{array}$ \\
\hline & & Subtilosin A1 & B. subtilis & 3412.5 & $\begin{array}{l}\text { Macrocyclic } \\
\text { antibiotic, } \\
\text { Variant. }\end{array}$ & $\begin{array}{l}\text { (Huang et } \\
\text { al., 2009) }\end{array}$ \\
\hline \multirow{7}{*}{$\begin{array}{l}\text { Class II: } \\
\text { Non modified } \\
\text { peptides }\end{array}$} & \multirow{4}{*}{$\begin{array}{l}\text { Subclass-II.1: } \\
\text { Pediocin-like } \\
\text { peptides }\end{array}$} & Coagulin & B. coagulans I4 & 4612 & $\begin{array}{l}\text { Pediocin-like } \\
\text { bacteriocin. }\end{array}$ & $\begin{array}{l}\text { (LeMarrec et } \\
\text { al., 2000) }\end{array}$ \\
\hline & & SRCAM 37 & $\begin{array}{l}\text { Paenibacillus } \\
\text { polymyxa } \\
\text { NRRL B-30507 } \\
\end{array}$ & 3000.5 & $\begin{array}{l}\text { Pediocin-like } \\
\text { bacteriocin; } \\
\text { anti-Campylobacter. }\end{array}$ & $\begin{array}{l}\text { (Svetoch et } \\
\text { al., 2005) }\end{array}$ \\
\hline & & SRCAM 602 & $\begin{array}{l}\text { Paenibacillus } \\
\text { polymyxa } \\
\text { NRRL B-30509 } \\
\end{array}$ & 3864 & $\begin{array}{l}\text { Pediocin-like } \\
\text { bacteriocin, } \\
\text { anti-Campylobacter. }\end{array}$ & $\begin{array}{l}\text { (Svetoch et } \\
\text { al., 2005) }\end{array}$ \\
\hline & & SRCAM 1580 & $\begin{array}{ll}\text { B. } & \text { circulans } \\
\text { NRRL } & \text { B-30644 }\end{array}$ & 3000.5 & $\begin{array}{l}\text { Pediocin-like } \\
\text { bacteriocin, } \\
\text { anti-Campylobacter: }\end{array}$ & $\begin{array}{l}\text { (Svetoch et } \\
\text { al., 2005) }\end{array}$ \\
\hline & \multirow{3}{*}{$\begin{array}{l}\text { Subclass-II.2: } \\
\text { Thuricin-like } \\
\text { peptides }\end{array}$} & Thurincin $\mathrm{H}$ & $\begin{array}{l}\text { B. thuringiensis } \\
\text { SF361 }\end{array}$ & 3139.51 & $\begin{array}{|lr|}\text { Three } & \text { structural } \\
\text { genes, } & \text { N-terminal } \\
\text { DWTXWSXL. }\end{array}$ & $\begin{array}{l}\text { (Lee et al., } \\
2009 b)\end{array}$ \\
\hline & & Thuricin S & $\begin{array}{l}\text { B. thuringiensis } \\
\text { ssp.entomocidus } \\
\text { HD198 }\end{array}$ & 3137.61 & $\begin{array}{l}\text { N-terminal: } \\
\text { DWTXWSXL. }\end{array}$ & $\begin{array}{l}\text { (Chehimi et } \\
\text { al., 2007) }\end{array}$ \\
\hline & & Thuricin 17 & $\begin{array}{l}\text { B. thuringiensis } \\
\text { NEB17 }\end{array}$ & 3160 & $\begin{array}{l}\text { N-terminal: } \\
\text { DWTXWSXL. }\end{array}$ & $\begin{array}{l}(\text { Lee et al., } \\
2009 a)\end{array}$ \\
\hline
\end{tabular}




\begin{tabular}{|c|c|c|c|c|c|c|}
\hline & & Bacthuricin F4 & $\begin{array}{l}\text { B. } \text { thuringiensis } \\
\text { ssp. kurstaki } \\
\text { BUPM4 }\end{array}$ & 3160.05 & $\begin{array}{l}\text { N-terminal: } \\
\text { DWTXWSXL. }\end{array}$ & $\begin{array}{l}\text { Kamoun et } \\
\text { al., 2005) }\end{array}$ \\
\hline & & Cerein MRX1 & B. cereus MRX1 & 3137.93 & $\begin{array}{l}\text { N-terminal: } \\
\text { DWTCWSCLVCA } \\
\text { ACSVELL. }\end{array}$ & $\begin{array}{l}\text { (Sebei et al., } \\
2007)\end{array}$ \\
\hline & $\begin{array}{l}\text { Subclass-II.3: } \\
\text { Other linear }\end{array}$ & Cerein 7A & $\begin{array}{l}\text { B. cereus Bc7 } \\
\text { (CECT 5148) }\end{array}$ & 3940 & $\begin{array}{l}\text { N-terminal: } \\
\text { GWGDVL. }\end{array}$ & $\begin{array}{l}\text { (Oscàriz et } \\
\text { al., 2006) }\end{array}$ \\
\hline & & Cerein 7B & $\begin{array}{l}\text { B. cereus Bc7 } \\
\text { (CECT 5148) }\end{array}$ & 4893 & $\begin{array}{l}\text { N-terminal: } \\
\text { GWWNSWGH, } \\
\text { Sec-independent } \\
\text { leader peptide with } \\
\text { GG. }\end{array}$ & $\begin{array}{l}\text { (Oscàriz et } \\
\text { al., 2006) }\end{array}$ \\
\hline & & Lichenin & $\begin{array}{l}\text { B. licheniformis } \\
\text { 26L-10/3RA }\end{array}$ & $\begin{array}{l}1400 \\
\text { to } 1500\end{array}$ & $\begin{array}{l}\text { N-terminal: } \\
\text { ISLEICXIFHDN. }\end{array}$ & $\begin{array}{l}\text { (Pattnaik et } \\
\text { al., 2001) }\end{array}$ \\
\hline & & Thuricin 439 & $\begin{array}{l}\text { B. thuringiensis } \\
\text { B439 }\end{array}$ & $\begin{array}{c}2803.8 \text { to } \\
2919.9\end{array}$ & $\begin{array}{l}\text { Two singly active } \\
\text { peptide. }\end{array}$ & $\begin{array}{l}\text { (Ahern et al., } \\
\text { 2003) }\end{array}$ \\
\hline $\begin{array}{l}\text { Class III: } \\
\text { Large } \\
\text { proteins }\end{array}$ & - & $\begin{array}{l}\text { Megacin A-216 } \\
\text { (with } \gamma, \alpha \text {, and } \\
\beta \text { chains) }\end{array}$ & $\begin{array}{l}\text { B. megaterium } \\
216\end{array}$ & $\begin{array}{l}3285,2102, \\
\text { and } 1185\end{array}$ & $\begin{array}{l}\text { Phospholipase A2 } \\
\text { activity, three } \\
\text { biologically active } \\
\text { Fractions } \\
\text { corresponding to } \\
\text { the full-length } \\
\text { protein(66000Da) } \\
\text { and two cleavage } \\
\text { products. }\end{array}$ & $\begin{array}{l}\text { (Kiss et al., } \\
2008)\end{array}$ \\
\hline & & $\begin{array}{l}\text { Megacin A- } \\
19213\end{array}$ & $\begin{array}{l}\text { B. megaterium } \\
\text { ATCC } 19213\end{array}$ & 39000 & $\begin{array}{l}\text { Phospholipase A2 } \\
\text { activity. }\end{array}$ & $\begin{array}{l}\text { (Kiss et al., } \\
2008)\end{array}$ \\
\hline
\end{tabular}

\section{Mode and mechanism of action Bacillus antimicrobial peptides Mode and mechanism of action of lipopeptides Mode of action of lipopeptides}

The lipopeptides, iturins, fengycins/plipastatins, and surfactins produced by Bacillus species display divers mechanisms of antimicrobial activities.

Iturins and fengycins possess strong fungitoxic and bactericidal effects against foodborne pathogenic and spoilage microorganisms (Savadogo et al., 2011). Members of the iturin family have fungitoxic effects, with a narrow antibacterial activity (Baindara et al., 2013). Surfactins are not fungitoxic but display synergistic effects on the iturin antifungal activity and possess exceptional anti-viral, and anti-mycoplasma activities (Peypoux et al., 1999).

\section{Mechanism of action of lipopeptides}

Lipopeptides exert their antimicrobial activities by binding to the bacterial surface bilayer and alter the local lipid organizational linkages on negatively-charged fatty acids, and ultimately restructuring the lipid bilayer and thus preventing cellular processes.

The member of iturin family, iturin A, bacillomycins and mycosubtilin form channels in bacterial cell membrane (Maget-Dana and Peypoux, 1994). Mycosubtilin alters the permeability of the plasma membrane and allow the diffusion of nucleotides, proteins and lipids (Peypoux et al., 1986). Bacillomycin L of B. amyloliquefaciens K103 strain exerts strong antifungal activity against filamentous fungi through fungal membrane permeabilization, and interaction with fungal DNA (Zhang et al., 2013).

Surfactins act synergistically on antifungal activity of iturin A. WH1 fungin, a new member of the surfactin family, exhibits two types of antifungal action: (a) the pores formation in the cell membrane when it is at high concentration and (b) apoptosis induction at its low concentration. WH1 fungin inhibits glucan synthase, resulting in decreased callose synthesis in the fungal cell wall, and also binds to the mitochondrial membrane ATPase and decreases its activity in fungal cells (Gaofu et al., 2010). 


\section{Mode and mechanism of bacteriocins \\ Mode of bacteriocins}

Bacteriocins display a high degree of target specificity of bactericidal activity, usually against closely related species to the producer strains, while other ones exert a wide spectrum of activity (Motta et al., 2007b). The mode of action of bacteriocins on a target cell is by adsorption on the cell surface followed by a lethal effect. It can be done by: (a) a bacteriostatic effect, inhibiting cell growth, (b) a bactericidal effect during which the bacteria die while maintaining their physical integrity because there was no cell lysis and (c) a bacteriolytic effect leading to dissolution or lysis of the bacterial (Da silva Sabo et al., 2014). The physiological state of the producer and the experimental conditions can influence the activity of the bacteriocins (Jasniewski, 2008), and the combination of several bacteriocins makes it possible to increase their activity and spectrum of action (Dortu and Thonart, 2009). Indeed, the mode of action of Bacillus bacteriocins differs from one group to another and was well detailed by Abriouel et al. (2011)

\section{Mechanism of bacteriocins}

Bacteriocins are generally cationic peptides, with hydrophobic or amphiphilic properties. The mechanism of action of bacteriocins often requires that they cross the negatively-charged outer cell wall of Gram-negative bacteria, which contains lipopolysaccharides, or outer cell wall of Gram-positive bacteria, which contains acidic polysaccharides. In many cases, specific metabolic activities of the target cells provide critical conditions for pores formation by bacteriocins (Pálffy et al., 2009).

Some bacteriocins, particularly those targeted the Gram-positive bacteria, usually interact directly with the bacterial cell membrane and cause membrane disruption, and ultimately cell death (Pálffy et al., 2009).

Majority of bacteriocins targets Lipid II, an intermediate in the peptidoglycan biosynthesis machinery within the bacterial cell envelope, and by this way they either induce the formation of pores in cytoplasmic membrane, through which ions can pass or inhibit peptidoglycan synthesis (Kuipers et al., 2011; Arias et al., 2013). For instance, mersacidin inhibits cell wall biosynthesis by forming a complex with lipid II across cytoplasmic membrane (Arias et al., 2013).

Killing of target cell via pores formation in its cytoplasmic membrane requires three principal steps: binding to the cell membrane, aggregation within the membrane, and formation of channels facilitating the leakage of internal cell contents and ultimately cell death (Abriouel et al., 2011).

Subtilisin forms the pores in cell membrane using its wall precursors lipid II as a docking module and undecaprenyl pyrophosphate as a central constituent of pores (Parisot et al., 2008).

Mersacidin binds the target bacterial cell wall precursor lipid II and thereby, inhibiting cell wall synthesis without modify the cell membrane permeability (Brötz et al., 1998).

Haloduracin and lichenicinin act at single-nanomolar concentrations via a dual mechanism of action which is facilitated by binding membrane lipid II and formation of pores (Abriouel et al., 2011).

Subtilosin depletes the transmembrane $\mathrm{pH}$ gradient $(\Delta \mathrm{pH})$ portion of the proton motor force (PMF) that allows an efflux of intracellular ATP, and ultimately the target cell death (Noll et al., 2011).

The Pediocin-like Bacteriocins bind the $\beta$ sheet of the target cell membrane leading to the dissipation of the PMF and the leakage of intracellular ATP (Kjos et al., 2010).

\section{Genetic organization and biosynthesis of Bacillus antimicrobial peptides Genetic organization and non-ribosomal biosynthesis of lipopeptides Genetic organization of lipopeptides.}

Non-ribosomal biosynthesis uses in addition to 20 amino acids of the genetic code, other non-proteogenic molecules such as non-proteogenic amino acids (D forms, hydroxylated, methylated), fatty acids, sugars, lipids and hydrates of carbon from other biosynthetic pathways (Savadogo et al., 2011). It is for this reason that the term "monomers" is used to designate these different precursor molecules incorporated in non-ribosomal peptides (Tambadou, 2014). 
Lipopeptides from Bacillus subtilis are synthesized by non-ribosomal peptide synthetases (NRPS) or by hybrid complex of polyketide synthetases (PKS) and NRPS (PKS-NRPS) (Marahiel and Essen, 2009). NRPS are megaenzymes (1000-1600 kDa) organized in iterative functional units called modules and that allows the production of peptides, which coding genes are often organized into operons (Schwarzer et al., 2003; Strieker et al., 2010). Each module is subdivided into main catalytic domains responsible for the activation of the monomer (adenylation, or Adomain), the elongation of the peptide chain (Peptidyl-Carrier-Protein, or PCP-domain/ Thiolation; or T-domain), and peptide bond formation (Condensation, or C-domain). (Sieber and Marahiel, 2005; Strieker et al., 2010).

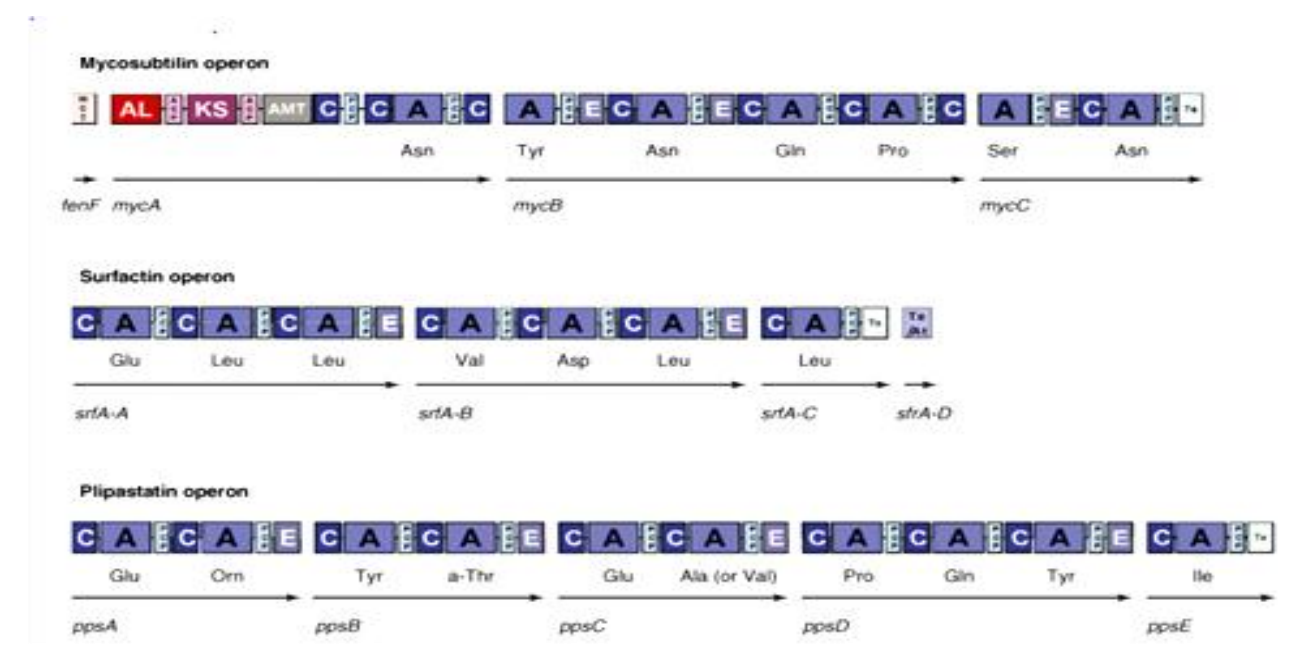

Figure 3:-The operons contain ORFs, domains of NRPSs or PKSs and amino acid incorporated by the different modules, and encoding catalytic machinery responsible for the biosynthesis of representative members of each family of lipopeptides. Source: Ongena et al. (2008).

The surfactin synthetases are coding by 3 large open reading frames (ORFs) designated srfA-A, srfA-B, and srfA-C that present a linear array of seven modules (one module per residue) (Fig.3) (Peypoux et al. 1999). SrfA-A and srfA-B hold each 3 modules and the last one in srfA-C. The addition of fatty acid chain is made from the amino acid activated in the first module. A first thioesterase links to the C-terminal end of the last activation PCP domain, which release the synthesized product from the enzymatic template. SrfA-D, a second thioesterase/acyltransferase (Te/At-domain) encoded by a fourth gene, stimulates the initiation of the biosynthesis (Steller et al., 2004).

Fengycins/plipastatins are also synthesized by NRPS encoded by an operon with five ORF ppsA-E (or fenA-E) (Fig. 3 ). The first three enzymes contain modules, the $4^{\text {th }}$ contains three modules and the last enzyme consists of one module (Ongena et al., 2008).

Iturin derivatives are synthesized by a PKS-NRPS hybrid complex unlikely to surfactin and fengycin (Stein, 2005). Iturin operon ranges from 38 to $40 \mathrm{~kb}$ in size and consists of four ORF, namely, fenF, mycA, mycB and mycC or ituD, ituA, ituB and ituC for mycosubtilin or iturin, respectively (Fig. 3) (Ongena et al., 2008). Three genes mycA (or ituA), mycB (or ituB) mycC (or ituC) encode for the NRPSs responsible for the incorporation of seven residues. The first one related to mycA (or ituA), the following four for mycB (or ituB) and the two last residues for mycC (or ituC). The structure of iturin A differs to that of mycosubtilin (in which the last amino acids are inverted) by an intragenic domain change in ituC and mycC. FenF (ituD) gene encodes a malonyl-CoA transacylase (MCT-domain). MycA also harbor PKSs related genes that are responsible for the final steps of the biosynthesis of the fatty acid chain (last elongation and $\beta$-amination) before it links up to the first amino acid of the peptidic moiety (Acyl-CoA ligase (AL-domain)) (Aron et al., 2005).

\section{Non-ribosomal biosynthesis of lipopeptides.}

Lipopeptides (iturins, surfactins and fengycins) are synthesized non-ribosomally via a multistep mechanism that involves the selection and condensation of amino-acid residues by modular megaenzymes NRPSs (Schwarzer et al., 2003). More than 300 different precursors are involved in the assemblage of these cyclic peptides, with possible branched structures containing a hydroxyl group, L-amino or D-amino acids, and furthermore modification by Nmethylation, acylation, glycosylation, or heterocyclic ring formation (Hancock and Chapple, 1999). 
Several B. subtilis strains synthetize the amphipathic antifungal lipopeptides iturin, bacillomycin, and fengycin through a thiotemplate mechanism controlled by NRPS consisted of modularly arranged catalytic domains (Baindara et al., 2013). However, in addition to thiotemplate mechanism, a quorum-sensing control mechanisms regulate the surfactin biosynthesis (Savadogo et al., 2011).

\section{Genetic organization and ribosomal biosynthesis of bacteriocins. Genetic organization of bacteriocins.}

The genes encode bacteriocins can be located on plasmids or on chromosomes (Kuipers et al., 2011). These genes are usually organized as an operon containing structural genes, immunity genes to protect the producer cell against its own synthesis, genes required for the transport and export of synthesized bacteriocin which are usually found on another locus and a gene encoding the leader peptide or prebacteriocin and genes for regulation (Jasniewski, 2008). A Quorum Sensing system mechanism regulates the bacteriocin production, and allows expression of certain genes according to the density of the bacterial population (Dortu and Thonart, 2009).

\section{Genetic organization of class I bacteriocins}

Genetic organization of subclass I.1 bacteriocins

The genes involved in the biosynthesis of lantibiotics can be located on a transposon, on the chromosome or on a plasmid (Kuipers et al., 2011).

Subtilin is the paradigm lantibiotic extensively studied in terms of its protein structure and genetic determinants. Subtilin is structurally similar to nisin (Fig. 4a), and their respective biosynthetic gene clusters encode highly similar proteins (Siezen et al., 1996). The biosynthesis of subtilin is based on the expression of at least 10 genes from gene clusters spaBTCSIFEGRK (Fig. 4a) including the structural gene spaS for its precursor, genes spaB and spaC forproteins dehydratase $(\mathrm{SpaB})$ and cyclase $(\mathrm{SpaC})$, respectively, responsible for the post-translational modification of the presubtilin (Siezen et al., 1996). The cluster also includes gene spaT for the transporter SpaT, which associates with a membrane complex containing the enzymes SpaB and SpaC (Stein et al., 2003) and genes spaIFEG for immunity against the cognate bacteriocin.

The two related lantibiotics ericin S and ericin A of B. subtilis A1/3, have strong similarities to subtilin (Stein et al., 2002a). The ericins gene cluster (Fig. 4a) contains two structural genes (eriA, eriS), with ORFs closely related to the corresponding genes of the subtilin cluster (Abriouel et al., 2011).

\section{Genetic organization of subclass I.2 bacteriocins}

The lantibiotic mersacidin gene cluster is located in a region that corresponds to $3481 \mathrm{kbp}$ on the chromosome of B. subtilis 168, (Fig. 4a) (Chatterjee et al., 1992). Its gene cluster contains 10 genes (spanning $12.3 \mathrm{kbp}$ ) including the structural gene mrsA, two genes (mrsM and mrsD) coding for precursor, one gene (mrsT) coding for a transporter with an associated protease domain and three genes (mrsF, mrsG, mrsE) coding for the group B, ABC Transporter involved in bacteriocin immunity (Altena et al., 2000). The cluster also includes three regulatory genes: two of them (mrsR2 and mrsK2) encode a two-component regulatory system apparently necessary for the transcription of the mrsFGE operon, and other gene mrsR1 encodes a protein involves in the regulation of mersacidin biosynthesis (Altena et al., 2000). 


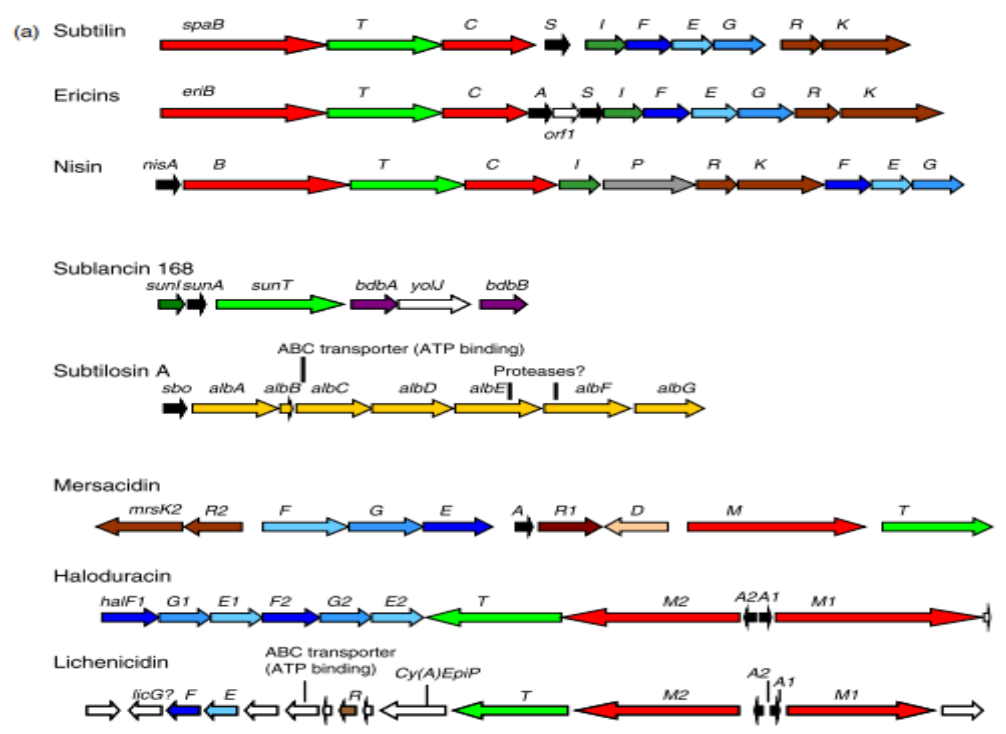

Figure 4:-(a) Schematic organization of gene clusters involved in the biosynthesis of Class I, post-translationally modified bacteriocins from Bacillus. The black arrows indicated the structural genes. The red and light green arrows indicate the genes involved in maturation and transport, respectively. Genes coding for transport proteins involved in bacteriocin immunity are indicated in blue colors, while those coding for specific immunity proteins (I) are denoted in dark green. The regulatory genes are colored in brown. The LAB bacteriocins nisin and lacticin 3147 gene clusters are used for comparison. (b) Organization of gene clusters involved in the biosynthesis of Class II and Class III bacteriocins from Bacillus. Structural genes are indicated in black. Other colors not specified denote gene functions not clearly conserved among the clusters or function unknown. Source: Abriouel et al. (2011)

The lantibiotic sublancin 168 gene cluster is located on the chromosome of the producer B. subtilis 168 (Paik et al., 1998). The sublancin operon consists of five genes for it production and one immunity gene (Fig. 4a). The genes for the production include the structural gene sunA identified from the SP $\beta$ prophage region of the B. subtilis 168 chromosome, and four successive genes (sunT, bdbA, yolJ and bdbB) located downstream of sunA (Serizawa et al., 2005). The ORF sunT encodes a bifunctional ABC transporter that contains an ATP-binding cassette domain and a proteolytic domain (McAuliffe et al., 2001). The genes dbA and bdbB coed for thiol-disulfide oxidoreductases (Kouwen et al., 2007), while the function of yolJ is unknown. Upstream of the structural gene sunA is located the sublancin immunity gene sunI that encodes an immunity protein SunI, a membrane protein with a single $\mathrm{N}$-terminal membrane-spanning domain (Dubois et al., 2009).

\section{Genetic organization of subclass I.3 bacteriocins}

Haloduracin from alkaliphile Bacillus halodurans C-125, consists of two post-translational peptides Hal $\alpha / \mathrm{A} 1$ and Hal $\beta / A 2$ processed by the enzymes HalM1 and HalM2 responsible for their post-translational modification, respectively. The bioinformatics analysis has allowed to identify 11 potential genes spanning a $15 \mathrm{kbp}$ region: the genes halA1 and A2 encode the haloduracin production, halM1, M2 code for modification, halt for transport and two sets of lanEFG homologs (halF1 to halE2) related to self-protection/immunity (Fig. 4a) (Lawton et al., 2007)

The two-peptide lantibiotic lichenicidin, produced by B. licheniformis ATCC 14580 and B. licheniformis DSM 13 (Dischinger et al., 2009), possesses a The gene cluster similar to that of haloduracin (Fig. 4a). Indeed, lichenicidin gene cluster contains both two structural genes (licA1, A2), two genes (licM1, M2) coding for dedicated modification proteins of the LanM type, and a putative gene (licT) involved in the export and cleavage of the leader peptides to obtain the mature lichenicidin A and B subunits. The cluster also contains at least one set of genes of the lanEFG type dedicated in lantibiotic immunity (Begley et al., 2009). Some studies on the structural gene have recorded that the mature $\alpha$-peptide Lica (Blia) (licA1, BLi04127) shared 40\% similarity with mersacidin (Bierbaum et al., 1995) and 38\% similarity with HalA1, while the mature $\beta$-peptide Licb(Blib) (licA2) showed 52\% similarity to the haloduracin $\beta$-peptide HalA2 (McClerren et al., 2006). 


\section{Genetic organization of subclass I.4 bacteriocins}

The operon coding for mature subtilosin A (Fig. 4a) consists of eight genes, sboA and albABCDEFG (Zheng et al., 2000). The sboA gene is an operon that encodes the proteins involve in presubtilosin processing and subtilosin export and immunity. The albABCDEFG genes, transcribed from a promoter residing upstream of the sboA gene, are involved in the post-translational modification of presubtilosin. (Abriouel et al., 2011). The operon of sbo-alb, induced under anaerobic conditions, is controlled by two types of regulatory proteins: the transition state regulatory protein AbrB, and the two-component regulatory proteins ResD and ResE responsible for gene expression in response to limiting oxygen supply (Nakano et al., 2000).

\section{Genetic organization of class II - bacteriocins}

Generally, the biosynthesis of class II-bacteriocins mobilizes at least seven genes including an inducer gene, gene for protein kinase, regulatory gene, precursor gene (coding for the prebacteriocin), immunity gene, gene for the $\mathrm{ABC}$ transporter and a last gene encoding the transport accessory protein (Abriouel et al., 2011).

\section{Genetic organization of subclass II.1 bacteriocins}

The genes encoding the pediocin-like bacteriocins are organized into one or two operons and are located either on a plasmid, either on the chromosome (Belguesmia et al., 2011). The genetic determinants (coa operon) of coagulinis located on $14 \mathrm{kbp}$ plasmid pI4 of its producer B. coagulans I4 (Le Marrec et al., 2000). These genetic determinants include an entire operon of four genes described for Pediococcus acidilactici pediocin PA-1/AcH (Fig. 4b), without the promoters for bacteriocin production. Downstream of the coa operon, a putative plasmid mobilization modules seem to be involved in plasmid transmission between bacteria (Le Marrec et al., 2000). The coagulin structural gene codes for a 44-amino-acid peptide similar to pediocin PA-1/ AcH, but possesses at position 41 a single C-terminal threonine residue, which is substituted by an asparagine (Asn41Thr) in a case of pediocin peptide. The coaB gene encodes bacteriocin immunity, while coaC and coaD are devoted to a secretion system mediated by an $\mathrm{ABC}$ transporter and its accessory protein, similar to those in P. acidilactici (Le Marrec et al., 2000).

\section{Genetic organization of subclass II.2 bacteriocins}

The B. thuringiensis thuricin 17 is encoded by three copies in tandem of the same structural gene (Fig. 4b). Each copy code for a 39-amino-acid precursor (Lee et al., 2009a). The three-gene copy is flanked upstream by secE gene encoding a protein translocase and nusG gene (a transcriptional anti-termination factor), and downstream by a sequence homologous to the albA gene of the subtilosin operon (Lee et al., 2009a).

The thurincin $\mathrm{H}$ (Fig. 4b). genetic determinants are held by bacterial chromosome. These genetic determinants consist of 10 ORFs including three structural genes (thnA1, A2 and A3) arranged in tandem repeats that are transcribed as a single transcript from a promoter upstream of the first structural gene as showed the RNA transcriptional analysis. The structural genes encode a 40-amino-acid prepeptide that evolves in a 31-amino-acid mature bacteriocin similar to thuricin 17 (Abriouel et al., 2011). The thurincin $\mathrm{H}$ structural genes are flanked downstream by a homologous gene to albA of thuricin $17(\mathrm{thnB})$, followed by thnT and thnI genes, whichencode a putative ABC-transport protein and a hypothetical immunity protein, respectively (Lee et al., 2009b). The thurincin $\mathrm{H}$ cluster upstream region differs from that reported for thuricin 17. This region contains the putative transcriptional regulator thnR, thnD for $\mathrm{ABC}$ transporter system (ATP-binding protein) and thnE for permease protein. ThnP together with ThnB seem to be involved in bacteriocin processing. Indeed, the product of thnP showed homology to the epidermin leader-peptide processing by serine peptidase EpiP and to AlbB of B. subtilis (Abriouel et al., 2011).

\section{Genetic organization of subclass II.3 bacteriocins}

The members of subclass II.3 bacteriocins, cerein 7A and 7B are two non-synergistic bacteriocins produced simultaneously by Bacillus cereus Bc7, and different by their N-terminal amino acid sequences N-Gly-Trp-Gly-AspVal-Leu (7A) and N-Gly-Trp-Trp-Asn-Ser-Trp-Gly-Lys (7B) (Oscáriz et al., 2006). Only cerein 7B is characterized at molecular level. The cell DNA sequencing shown an ORF in the 416 contiguous nucleotides sequence that encoded a 74-amino acid protein containing a 18-amino acid leader sequence followed by 56 amino acids, corresponding to the mature cerein 7B, which structural gene promoter (Pribnow box) consisted of two 8 bp inverse repeats spanned by a 8 bp AT-rich region (Oscáriz et al. 2006).

\section{Genetic organization of Class III bacteriocins}

The large proteins megacin A-216 and megacin A-19213 produced by B. megaterium 216 and B. megaterium ATCC 19213, have their structural and immunity genes encoded on 211pBM309 (48 kb) and pBM113 (44 kb) 
plasmid region in each Bacillus strains, respectively (Abriouel et al., 2011). The genetic determinants of megacin A216 (Fig. 4b) encoded by a 5.494-bp plasmid region, include the structural gene megA, that codes for 293-aminoacid protein similar to proteins with phospholipase A2 activity, followed by an ORF encoding a 91-amino-acid protein dedicates to the producer self-protection. ORF 73 and gene encoding a 188-amino-acid protein similar to RNA polymerase factors, are at least required for the induction of megacin A-216 expression (Abriouel et al., 2011).

\section{Ribosomal biosynthesis of bacteriocins of Bacillus}

All bacteriocins are produced ribosomally in the cytoplasm of the producer cell as an inactive precursor called prebacteriocin recognized by the $\mathrm{ABC}$ transporter (ATP Binding Cassette transporter), which cleaves during or immediately after secretion to allow the bacteriocin to be active (Chen andHoover, 2003, Makhloufi, 2011).

Furthermore, biosynthesis mechanism of class I bacteriocins involves variety of unusual amino acids (Abriouel et al., 2011). During maturation, the premature lantibiotics (precursor peptides) undergo intramolecular posttranslational modifications through the dehydration of serine and threonine residues and subsequent intramolecular addition of unusual thioether amino acids such as lanthionine and/or methyllanthionine residues to cysteine (Chatterjee et al., 2005). This addition results in the formation of ( $\beta$-methyl) lanthionine thioether bridges, the characteristic structural elements for lantibiotics (Bierbaum and Sahl, 2009), together with the proteolytic removal of leader peptides (Dischinger et al., 2009).

\section{Application of antimicrobial peptides produced by Bacillus strains}

Bacillus antimicrobial peptides, given to their safety, received more attention todays for several applications such as biomedical and therapeutic, pharmaceutical and food applications (Abriouel et al., 2011). Only food applications of lipopeptides and bacteriocins produce by Bacillus species are discussed and the other applications being beyond of the scope of this review.

To date, consumer demands for minimally processed foods or 'fresh foods' without chemical preservatives have stimulated research interest in the new bioconservation methods (Abriouel et al., 2011; Silva et al., 2018). The bioconservation of a food is to increase its shelf life and improve its safety by using microorganisms and/or their metabolites (Ross et al., 2002). Indeed, the screening of antimicrobial peptides for food applications requires the fulfillment of some extensive criteria (EFSA, 2008). Producer strains should be food grade (GRAS or QPS), exhibit a broad spectrum of inhibition, exert high specific activity, have health risks free, present beneficial effects (e.g. improve safety, quality, and flavor of foods), display heat and $\mathrm{pH}$ stability, and optimal solubility and stability for a particular food (Mills et al., 2011). Antimicrobial peptides-producing Bacillus strains or their peptides, which meet the above criteria, could be used as safe food biopreservatives even thought, their applications are rarely evaluated compared to LAB bacteriocins (e.g. nisin and pediocin PA1), which have the GRAS status (Simha et al., 2012).

In the food industry, lipopeptides are used as emulsifiers during processing of raw materials. The baking industry uses surfactins to maintain the texture, stability, and volume of fat, and also its emulsification (Mandal et al., 2013).

An increasing interest is also granted to Bacillus bacteriocins for food preservation since they are superior to LAB bacteriocins (Abriouel et al., 2011). Usually, the use of bacteriocins as food preservatives includes the main following approaches: inoculation of food with the bacteriocin-producing strain (starters culture or protective cultures), useof food previously fermented with a bacteriocin-producing strain as an ingredient in food processing, and the addition of purified or semi-purified bacteriocin as food additives, with the requirement of express authorization of their use. (Chen and Hoover, 2003; Cotter et al., 2005b). Inactivation of foodborne pathogens by bacteriocins may differ greatly depending on the food matrix used, and thus, their effectiveness must be tested in all food systems (Taalé et al., 2015). Good examples are the antimicrobial peptides paenibacillin (He et al., 2007), P34 (Motta et al., 2008), etc...

Unfortunately, there are not enough data on the possible applications of lipopeptides and bacteriocins produced by the various mains Bacillus strains isolated from African indigenous alkaline-fermented food condiments. However, application of lipopeptide- or bacteriocin-producing Bacillus strains in these food condiments and beverage substrates know new opportunities in food biopreservation. Hence, subtilisin-producing B. subtilis strain, an inhibitor of toxin-producing B. cereus, has been suggested as starter culture to improve the safety in the production of okpehe (Oguntoyinbo et al., 2010). BLIS-producing B. subtilis B7 and B15 strains has been proposed as starter cultures for soumbala production (Ouoba et al., 2008a). Strains B. subtilis subsp. subtilis H4 and B. amyloliquefaciens ssp. plantarum produced both lipopeptides (iturins, surfactins and fengycins) and bacteriocins 
active against B. cereus, L. monocytogenes, M. luteus and S. aureus, and has been proposed as a useful starter cultures for safe production and biopreservation of Bikalga (Compaoré et al. (2013a, c). BLIS-producing B. subtilis, with a wide antimicrobial spectrum, has promising application in food biopreservation (Taale et al., 20015).

\section{Economic impact of antimicrobial peptides.}

The sale values of food additives are knowing continuous growth rates about 2 to $3 \%$ annually, and especially for emulsifiers and hydrocolloids in terms of market increase (Freire et al., 2009). It is quite likely that lipopeptides and bacteriocins produced by Bacillus species, in the near future, will represent significant percentage of food additive in the market.

The bacteriocins are used in purified, semi-purified form or in the form of a concentrate obtained after fermentation of a food substrate (Makhloufi, 2011). It is difficult to condition the bacteriocins in purified form because their purification is expensive and it requires several steps (precipitation -chromatography on column -reverse phase HPLC), hence difficulties for production on an industrial scale. Adsorption technique is most used because of the cationic nature of bacteriocins. Several forms of conditioning of bacteriocins are to date proposed: adsorption of bacteriocins in silicone particles, encapsulation in liposomes or incorporation into different materials (calcium aliginate, cellulose, soy protein, polysaccharide films), and freeze-dried (Sutyak et al., 2008b). All these problems encountered in the production and packaging of bacteriocins explain their low rate of use as a food preservative or for other applications. Nevertheless, the bacteriocin trade has an annual growth rate of 2-3\% and has reached a turnover of over US \$ 24 billion in 2007 (Jones et al., 2005). Actually, only nisin (Nisaplin, Danisco) and pediocin PA1 (MicrogardTM, ALTA 2431, Quest) have been authorized by FAO and commercialized as food preservatives (Simha et al., 2012). In recent years the production and marketing of various bacteriocins have reached record values because of the annual growth rate. Today we have a turnover of more than 50 billion US Dollars. The main producing companies are Danisco A / S (Denmark), Royal DSM (Holland), Kerry Group Plc (Ireland), Rhodia S.A. (France), Sysco Foods (USA), Schreiber Foods (USA), etc.

\section{Implications antimicrobial peptides for food safety and shelf-life}

Several studies have demonstrated that the desirable Bacillus strains from alkaline-fermented foods produce useful lipopeptides and bacteriocins that exert some broader spectra against spoilage and pathogenic microorgisms (Ouoba et al., 2008). Thereby, these antimicrobial peptides contribute to food safety and enhance it shelf-life (Compaoré et al., 2013b, c; Nah et al., 2015). However, efforts still have to be made to use desirable Bacillus strains and/or their antimicrobial peptides, either alone or in combination with the mild physicochemical treatments and low concentrations of traditional and natural chemical preservative, as an efficient way of extending shelf-life and food safety through the inhibition of spoilage and pathogenic bacteria without altering the nutritional value of food products in order to meet the consumer demands.

\section{Conclusion and future perspectives}

Bacillus species particularly the member of Bacillus subtilis group are the main bacteria involve in the plant-based seeds bioconversion for African alkaline-fermented food condiments production. The indigenous alkaline fermented condiments are being promoted in some countries due to their beneficial role in the diet, and there is increasing demand for such products in both rural and urban areas. Indeed, the ability of many Bacillus strains to produce lipopeptides and bacteriocins, mainly active against foodborne spoilage and pathogens, and human and/or animal pathogens, leads to suppose that the GRAS status could be further extended to some Bacillus species and/or their antimicrobial peptides for food productions in industrial level. Several studies shown that lipopeptides and bacteriocins represent a group of bioactive molecules with a diversity of structures offering a broad spectrum of physico-chemical properties that can lead to various industrial applications, meeting the needs of consumers and industries. Scientists and industrialists are increasingly interested in the biological activities of these molecules and their potential food applications as well in other fields. On this point, the scientific literature is regularly enriched with data relating to the potential antimicrobial peptides for applications in different life sector.

\section{Conflict of Interests statements}

The authors declare that there is no conflict of interest for this article.

\section{Acknowledgments:-}


This work has been done in Université Ouaga I, Pr. Joseph KI-ZERBO, Burkina Faso and University of Nigeria, Nsukka, Nigeria. The authors are also thankful to the Germany DAAD service for the financial support to one of the authors (DABIRE Yérobessor) through it in Region/In country scholarship programme in the University of Nigeria Nsukka. We need also to thank International Sciences Programm (ISP, Sweden).

\section{References}

1. Abaelu, A.M., Olukoya, D.K., Okochi, VI., and Akinrimisi E.O. (1990): Biochemical changes in fermented Melon Egusi, seeds Citrullis Vulgaris. J. Industrial Microbiol., 6: 211-214.

2. Abriouel, H., Franz, C.M.A.P., Omar, N. B., and Gálvez A. (2011): Diversity and applications of Bacillus bacteriocins. FEMS Microbiol. Rev. 35(1): 201-232. doi:10.1111/j.1574-576 6976.2010.00244.

3. Ahern M., Verschueren, S., and van Sinderen D. (2003): Isolation and Characterization of a novel bacteriocin produced by Bacillus thuringiensis strain B439. FEMS Microbiol. Lett., 163: 229-236.

4. Akpa, E., Jacques P., Wathelet B. et al. (2001): Influence of culture conditions on lipopeptide production by Bacillus subtilis. Appl. Biochem. and Biotechnol. -Part A Enzy. Engin. Biotechnol., 91(93): 551-561.

5. Altena, K., Guder, A., Cramer, C., and Bierbaum, G. (2000): Biosynthesis of the lantibiotic mersacidin: organization of a type B lantibiotic gene cluster. Appl. Environ. Microbiol., 66: 2565-2571.

6. Alvarez-Sieiro, P., Montalbán-López, M., Mu, D., and Kuipers, O.P. (2016): Bacteriocins of lactic acid bacteria: extending the family. Appl. Microbiol. Biotechnol., 100: 2939-2951. doi: 10.1007/s00253-016-7343-9

7. Aranda, F. J., Teruel, J.A., and Ortiz, A. (2005): Further aspects on the hemolytic activity of the antibiotic lipopeptide iturin A. Biochimica et Biophysica Acta-Biomembranes., 1713(1): 51-56.

8. Arias, A.A., Ongena, M., Devreese, B., Terrak, M., Jiri's, B., and Fickers, P. (2013): Characterization of amylolysin, a novel lantibiotic from Bacillus amyloliquefaciens GA1. PLOS One. 8: e83037. doi: 10.1371/journal.pone.0083037.

9. Arnison, P. G., Bibb, M. J., Bierbaum, G., Bowers, A. A., Bugni, T. S., Bulaj, G., et al. (2013): Ribosomally synthesized and post-translationally modified peptide natural products: overview and recommendations for a universal nomenclature. Nat. Prod. Rep., 30: 108-160.doi: 10.1039/c2np20085f.

10. Aron, Z.D. et al. (2005): Characterization of a new tailoring domain in polyketide biogenesis: The amine transferase domain of MycA in the mycosubtilin gene cluster. J. Am. Chem. Soc., 127: 14986-14987.

11. Azokpota, P., Hounhouigan, D. J, Nago, M.C., and Jakobsen M. (2006): Esterase and protease activities of Bacillus spp. from afitin, iru and sonru: three African locust bean (Parkia biglobosa) condiments from Benin. African J. Biotechnol., 5(3): 265 - 272.

12. Azokpota, P., Hounhouigan, D.J., Annan, N.T., Nago, M.C., and Jakobsen M. (2008): Diversity of volatile compounds of afitin, iru and sonru, three fermented food condiments from Benin. World J. Microbiol. Biotechnol., 24: 879-885.

13. Babasaki, K., Takao, T., Shimonishi, Y., and Kurahashi, K. (1985). Subtilosin A, a new antibiotic peptide produced by Bacillus subtilis 168: isolation, structural analysis, and biogenesis. J. Biochem. (Tokyo)., 98(3): 585 - 603. PMID:3936839.

14. Baindara, P., Mandal, S.M., Chawla, N., Singh, P.K., Pinnaka, A.K., and Korpole, S. (2013). Characterization of two antimicrobial peptides produced by a halotolerant Bacillus subtilis strain SK.DU.4 isolated from a rhizosphere soil sample. AMB Express., 3(1): 2. doi:10.1186/2191-0855-3-2.

15. Barbosa, T.M., Serra, C.R., La Ragione, R.M., Woodward, M.J., and Henriques A.O. (2005). Screening for Bacillus isolates in the broiler gastrointestinal tract. Appl. Environ. Microbiol., 71: 968-978.

16. Begley, M., Cotter, P.D., Hill, C., and Ross, R.P. (2009): Identification of a Novel Two-Peptide Lantibiotic, Lichenicidin, following Rational Genome Mining for LanM Proteins. Appl. Environ. Microbiol., 75: 5451-5460.

17. Belguesmia, Y., Naghmouchi, K., Chihib, N.E., and Drider, D. (2011): Class IIa bacteriocins: current knowledge and perspectives. In Drider D et Rebuffat S (Ed.), Prokaryotic antimicrobial peptides: From genes to applications. New York: Springer, p171-195. doi: http://dx.doi.org/10.1007/978-1-4419-7692-5_10.

18. Bierbaum, G., and Sahl, H.G. (2009): Lantibiotics: mode of action, biosynthesis and bioengineering. Curr. Pharm. Biotechno.,10: 2-18.

19. Bierbaum, G., Brötz, H., Koller, K.P., and Sahl, H.G. (1995): Cloning, sequencing and production of the lantibiotic mersacidin. FEMS Microbiol. Lett., 127: 121-126.

20. Brötz, H., Bierbaum, G., Leopold, K., Reynolds, P.E., and Sahl, H.G. (1998): The lantibiotic mersacidin inhibits peptidoglycan synthesis by targeting lipid II. Antimicrob. Agents. Ch., 42: 154-160.

21. Chatterjee, C., Paul, M., Xie, L., and van der Donk, W.A. (2005): Biosynthesis and mode of action of lantibiotics. Chem. Rev.,105: 633-684. 
22. Chatterjee, S., Chatterjee, S., Lad, S.J., Phansalkar, M.S., Rupp, R.H., Ganguli, B.N., Fehlhaber, H.W., and Kogler, H. (1992): Mersacidin, a new antibiotic from Bacillus. Fermentation, isolation, purification and chemical characterization. J. Antibiot. (Tokyo)., 45(6): 832-838. doi:10.7164/antibiotics.45.832.

23. Chehimi, S., Delalande, F., Sable, S., Hajlaoui, M.R., Van Dorsselaer, A., Limam, F., and Pons, A.M. (2007): Purification and partial amino acid sequence of thuricin S, a new anti-Listeria bacteriocin from Bacillus thuringiensis. Can. J. Microbiol., 53: 284-90.

24. Chen, H., and Hoover, D.G. (2003): Bacteriocins and their food applications. Compr. Rev. Food Sci. Food Safety., 2(3): 82-100. doi: http://dx.doi.org/10.1111/j.1541-4337.2003.tb00016.x

25. Compaore, C.S., Jensen, L. B., Diawara, B., Ouédraogo, G. A., Jakobsen, M., and Ouoba, L.I. I. (2013c): Resistance to antimicrobials and acid and bile tolerance of Bacillus spp. isolated from Bikalga, fermented seeds of Hibiscus sabdariffa. African J. Food Sci., 7(11): 408-414. doi: 10.5897/AJFS2013.1018.

26. Compaoré, C.S., Nielsen, D. S., Ouoba, L.I.I., Berner, T. S., Nielsen, K. F., Sawadogo-Lingani, H., Diawara, B., Ouédraogo, G.A., Jakobsen, M., and Thorsen, L. (2013a): Co-production of surfactin and a novel bacteriocin by Bacillus subtilis subsp. subtilis H4 isolated from Bikalga, an African Alkaline Hibiscus sabdariffa seed fermented condiment. Int. J. Food Microbiol., 162: 297-307

27. Compaoré, C.S., Nielsen, D.S., Sawadogo-Lingani, H., Berner, T.S., Nielsen, K.F, Adimpong, B.D., Diawara, B., Ouedraogo, G.A., Jakobsen, M., and Thorsen, L. (2013b): Bacillus amyloliquefaciens ssp. plantarum strains as potential protective starter cultures for the production of Bikalga, an alkaline fermented food. J. Appl. Microbiol., 115: 133-146.

28. Cotter, P. D, Hill C., et Ross, R.P. (2005b): Bacteriocins: developing innate immunity for food. Nat. Rev. Microbiol., 3(10): 777-788. doi: http://dx.doi.org/10.1038/nrmicro1273.

29. Cotter, P.D., Ross, R.P., and Hill, C. (2013): Bacteriocins-available alternative to antibiotics? Nat. Rev. Microbiol.,11(2): 95-105. doi :10.1038/nrmicro2937. PMID:23268227.

30. Da Silva Sabo, S., Vitolo, M., González, J.M.D., and De Souza Oliveira, R.P. (2014): Overview of Lactobacillus plantarum as a promising bacteriocin producer among lactic acid bacteria. Food Res. Int., 64: 527-536. doi: 10.1016/j.foodres.2014.07.041.

31. Dischinger, J., Josten, M., Szekat, C., Sahl, H. G., and Bierbaum, G. (2009): Production of the novel two-peptide lantibiotic lichenicidin by Bacillus licheniformis DSM 13. PLoS One., 4(8): e6788. doi: 10.1371/journal.pone.0006788.

32. Dortu, C., and Thonart, P. (2009) : Les bactériocines des bactéries lactiques : caractéristiques et intérêts pour la bioconservation des produits alimentaires. Biotechnologie Agronomie Société et Environnement., 13(1): 143154.

33. Dubois, J.Y.F., Kouwen, T.R.H.M., Schurich, A.K.C., Reis, C.R., Ensing, H.T., Trip, E.N., Zweers, J.C., and van Dijl, J.M. (2009): Immunity to the bacteriocin sublancin 168 is determined by the SunI (YolF) protein of Bacillus subtilis. Antimicrob. Agents Ch., 53: 651-661.

34. EFSA (2008): The maintenance of the list of QPS microorganisms intentionally added to foods or feeds. Scientific opinion of thepanel on biological hazards. EFSA J., 923: 1- 48.

35. Ejiofor, M.A.N., Oti, E., and Okafor, J.C. (1987): Studies on the fermentation of seeds of the African oil bean tree Pentaclethra macrophylla. Int. Tree Crops J., 4: 135-144.

36. Eze, V. C., Onwuakor, C. E., and Ukeka, E. (2014): Proximate composition, biochemical and microbiological changes associated with fermenting African oil bean (Pentaclethra macrophylla Benth) seeds. Amer. J. Microbiol., 2: 674-681.

37. Feng, G., Guron, G.K.P., Churey, J.J., and Worobo, R.W. (2009): Characterization of mundticin L, a class IIa anti-Listeria bacteriocin from Enterococcus mundtii CUGF08. App. Environ. Microb., 75(17): 5708-5713. doi: http://dx.doi.org/10.1128/AEM.00752-09.

38. Fernandez, B. (2014) : Activité biologique et impact sur le microbiote intestinal des bactéries lactiques bactériocinogènes. PhD thesis, Université Laval, Québec, 143p.

39. Freire, D.M.G., Araujo, L.V.D., Kronemberger, F.D.A. et al. (2009): Innovation in Food Engineering, CRC Press, New York, NY, USA.

40. Gálvez, A., Abriouel, H., López, R.L., and Omar, N.B. (2007): Bacteriocin-based strategies for food biopreservation. Int. J. Food Microbiol., 120: 51-70.

41. Guder, A., Wiedemann, I. and Sahl H.G. (2000): Post-translationally modified bacteriocins: the lantibiotics. Biopolymers. 55: 62-73.

42. He, Z., Kisla, D., Zhang, L., Yuan, C., Green-Church, K.B., and Yousef, A.E. (2007): Isolation and identification of a Paenibacillus polymyxa strain that coproduces a novel lantibiotic and polymyxin. Appl. Environ. Microbiol., 73: $168-178$.

43. He, Z., Yuan, C., Zhang, L., and Yousef, A.E. (2008): N-terminal acetylation in paenibacillin, a novel lantibiotic. FEBS Lett., 582: 2787-2792. 
44. Holo, H., Jeknic, Z., Daeschel M., Stevanovic S., and Nes, I.F. (2001): Plantaricin W from Lactobacillus plantarum belongs to a new family of two-peptide lantibiotics. Microbiology., 147: 643-651.

45. Hong, H.A., Duc le, H., and Cutting, S.M. (2005): The use of bacterial spore formers as probiotics. FEMS Microbiol. Rev., 29: 813-835.

46. Huang, T., Geng, H., Miyyapuram, V.R., Sit, C.S., Vederas, J.C., and Nakano, M.M. (2009): Isolation of a variant of subtilosin A with hemolytic activity. J. Bacteriol., 191(18): 5690-5696. doi:10.1128/JB.00541-09.

47. Hwang, A. L., and Jeong H.K. (2012): Isolation of Bacillus amyloliquefaciens strains with antifungal activities from Meju. Prev. Nutr. Food Sci.,17: 64-70. http://dx.doi.org/10.3746/pnf.2012.17.1.064.

48. Inatsu, Y, Nakamura, N, Yuriko, Y, Fushimi, T, Watanasiritum, L, and Kawamoto, S (2006): Characterization of Bacillus subtilis strains in Thua nao, a traditional fermented soybean food in Northern Thailand. Lett. Appl. Microbiol., 43: 237-242.

49. Jasniewski, J. (2008). Étude des mécanismes d'action de bactériocines de la sous-classe IIa. PhD thesis, NancyUniversité, Nancy, 155p.

50. Jones, E., Salin V., and Williams, G.W. (2005): Nisin and the market for commercial bacteriocins TAMRC Consumer and Product Research Report No. CP-01-05 (pp. 25). Texas: Texas A \& M University.

51. Kabore, D., Thorsen, L., Nielsen, S.D., Berner, S.T., Sawadogo-Lingani, H., Diawara, B., Dicko, H.M., Jakobsen, M., (2012): Bacteriocin formation by dominant aerobic spore formers isolated from traditional maari. Int. J. Food Microbiol., 154: 10-18.

52. Kamoun, F., Fguira, I.B., Tounsi, A., Abdelkefi-Mesrati, L., Sanchis, V., Lereclus, D. and Jaoua S. (2009): Generation of mini-Tn10 transposon insertion mutant library of Bacillus thuringiensis for the investigation of genes required for its bacteriocin production. FEMS Microbiol. Lett., 294: 141-149.

53. Khem R.M., and Shamsher S. K. (2015): Review Article. Lipopeptides as the Antifungal and Antibacterial Agents: Applications in Food Safety and Therapeutics. BioMed. Res. Int., Volume 2015 : Article ID 473050, 9 pages. http://dx.doi.org/10.1155/2015/473050.

54. Kim, P. I., Bai, H., Bai, D., et al. (2004): Purification and characterization of a lipopeptide produced by Bacillus thuringiensis CMB26. J. Appl. Microbiol., 97(5): 942-949.

55. Kiss, A., Baliko, G., Csorba, A., Chuluunbaatar, T., Medzihradszky, K.F., and Alföldi, L. (2008): Cloning and characterization of the DNA region responsible for megacin A-216 production in Bacillus megaterium 216. J. Bacteriol.,190: 6448-6457.

56. Kjos, M., Salehian, Z., Nes, I.F., and Diep, D.B. (2010): An extracellular loop of the mannose phosphotransferase system component IIC is responsible for specific targeting by class IIa bacteriocins. J. Bacteriol., 192(22): 5906-5913. doi: http://dx.doi.org/10.1128/JB.00777-10.

57. Klaenhammer, T.R. (1993): Genetics of bacteriocins produced by lactic acid bacteria. FEMS Microbiol. Rev., 12(1-3): 39-86. doi:10.1016/0168-6445(93)90057-G.

58. Korenblum, E., De Araujo, L.V., Guimaraes, C.R., et al. (2012): Purification and characterization of a surfactinlike molecule produced by Bacillus spp. H2O-1 and its antagonistic effect against sulfate reducing bacteria. BMC Microbiol.,12(1): 252.

59. Kouwen, T.R., van der Goot, A., Dorenbos, R., Winter, T., Antelmann, H., Plaisier, M.C., Quax, W.J., van Dijl, J.M., and Dubois, J.Y. (2007): Thiol-disulphide oxidoreductase modules in the low-GC Gram-positive bacteria. Molecular Microbiology., 64: 984-999.

60. Kuipers, A., Rink, R., and Moll, G.N. (2011): Genetics, biosynthesis, structure, and mode of action of lantibiotics. In Drider D et Rebuffat S (Ed.), Prokaryotic Antimicrobial Peptides: From Genes to Applications. New York: Springer, USA, p147-169. doi: http://dx.doi.org/10.1007/978-1-4419-7692-5_9.

61. Lawton, E. M., Cotter, P. D., Hill, C., and Ross, R. P. (2007): Identification of a novel two-peptide lantibiotic, Haloduracin, produced by the alkaliphile Bacillus halodurans C-125. FEMS Microbiol. Lett., 267(1): 64-71. doi:10.1111/j.1574-6968.2006.00539.

62. Le Marrec, C., Hyronimus, B., Bressollier, P., Verneuil, B., Urdaci, M.C. (2000): Biochemical and genetic characterization of coagulin, a new antilisterial bacteriocin in the pediocin family of bacteriocins, produced by Bacillus coagulans I4. Appl. Environ. Microbiol., 66: 5213-5220.

63. Lee, H., Churey, J.J. and Worobo, R.W. (2009b): Biosynthesis and transcriptional analysis of thurincin H, a tandem repeated bacteriocin genetic locus, produced by Bacillus thuringiensis SF361. FEMS Microbiol. Lett., 299: 205-213.

64. Lee, KD, Gray., E.J, Mabood, F., Jung, W.J., Charles, T., Clark, S.R., Ly, A., Souleimanov, A., Zhou, X., and Smith D.L. (2009a): The class IId bacteriocin thuricin-17 increases plant growth. Planta., 229: 747-55.

65. Maget-Dana, R., and Peypoux, F. (1994): Iturins, a special class of pore-forming lipopeptides: biological and physicochemical properties. Toxicology., 87(1-3): 151-74.

66. Makhloufi, K.M. (2011). Caractérisation d'une bactériocine produite par une bactérie lactique Leuconostoc pseudomesenteroides isolée du boza. PhD Thesis, Université Pierre et Marie Curie-Paris VI, Paris, 228p. 
67. Mandal, S.M., Barbosa A.E.A.D., and Franco, O. L. (2013): Lipopeptides in microbial infection control: scope and reality for industry. Biotechnol. Adv., 31(2): 338-345.

68. Marahiel, M.A., and Essen, L.O. (2009): Non-ribosomal peptide synthetases: mechanistic and structural aspects of essential domains. Methods in Enzymology., 458: 337-351.

69. Marx, R., Stein, T., Entian, K.D., and Glaser, S.J. (2001): Structure of the Bacillus subtilis peptide antibiotic subtilosin A determined by 1H-NMR and matrix assisted laser desorption/ionization time-of-flight mass spectrometry. J. Protein. Chem., 20(6): 501-506. PMID:11760125.

70. McAuliffe, O., Ross, R.P. and Hill, C. (2001): Lantibiotics: structure, biosynthesis and mode of action. FEMS Microbiol. Rev., 25: 285-308.

71. McClerren, A.L., Cooper, L.E., Quan, C., Thomas, P.M., Kelleher, N.L., and van der Donk, W.A. (2006): Discovery and in vitro biosynthesis of haloduracin, a two-component lantibiotic. P. Natl. Acad. Sci. USA. 103: 17243-17248.

72. Mills, S., Serrano, L., Griffin, C., O’connor, P.M., Schaad, G., Bruining, C., et al. (2011): Inhibitory activity of Lactobacillus plantarum LMG P-26358 against Listeria innocula when used as an adjunct starter in the manufacture of cheese. Microbial Cell Factories., 10, S7. doi: 10.1186/1475-2859-10-S1-S7.

73. Motta, A.S., Cannavan, F.S., Tsai, S., Brandelli, A. (2007b): Characterization of a broad range antibacterial substance from a new Bacillus species isolated from Amazon basin. Arch. Microbiol., 188: 367-375.

74. Motta, A.S., Flores, F.S., Souto, A.A., and Brandelli, A. (2008): Antibacterial activity of a bacteriocin-like substance produced by Bacillus spp. P34 that targets the bacterial cell envelope. Antonie. Van Leeuwenhoek., 93(3): 275-284. doi:10.1007/s10482-007-9202-2.

75. Nakano, M.M., Zheng, G., and Zuber, P. (2000): Dual control of sbo-alb operon expression by the Spo0 and ResDE systems of signal transduction under anaerobic conditions in Bacillus subtilis. J. Bacteriol., 182: 32743277.

76. Nath S., Chowdhury S., and K.C. Dora. (2015): Application of Bacillus spp. as a biopreservative for food preservation. Journal of Engineering Research and Applications., ISSN: 2248-9622, 5(4): 85-95.

77. Ndir, B., Hbid, C., Cornelius, C., Roblain, D., Jacques, P., Vanhentenryck, F., Diop, M., and Thonart, P. (1994). Propriétés antifongiques de la microflore sporulée du nététu. Cahiers Agricultures., $3: 23-30$.

78. Nes, I.F., Yoon S.S., and Diep, D.B. (2007): Ribosomally synthesized antimicrobial peptides (bacteriocins) in lactic acid bacteria: a review. Food Sci. Biotechnol., 16: 675-690.

79. Nicholson, W. (2002): Roles of Bacillus endospores in the environment. Cell. Mol. Life Sci. 59(3): 410-416. doi: http://dx.doi.org/10.1007/s00018-002-8433-7.

80. Noll, K.S., Sinko, P.J., and Chikindas, M.L. (2011): Elucidation of the molecular mechanisms of action of the natural antimicrobial peptide subtilosin against the bacterial vaginosis-associated pathogen Gardnerella vaginalis. Probiotics \& Antimicro. Prot., 3(1): 41-47. doi:10.1007/s12602-010-9061-4.

81. Nurudeen A. O., Chimezie P.O., and Folarin A. O. (2016): The Biotechnology of Ugba, a Nigerian Traditional Fermented Food Condiment. Front. Microbiol., 7: 115. doi:10.3389/fmicb.2016.01153.

82. Odunfa, S., and Oyewole, O. (1986): Identification of Bacillus species from 'iru', a fermented African locust bean product. J. Bas. Microbiol., 26(2): 101-108.

83. Ogunshe, A. A.O., Ayodele A.E., and Okonko I.O. (2006): Microbial studies on aisa: a potential indigenous laboratory fermented food condiment from Albizia saman Jacq, F. Mull. Pakistan J. Nutrit., 5: 51-58.

84. Ogunshe, A.A.O., Omotosho, M.O., and Ayansina A.D.V. (2007): Microbial studies and biochemical characteristics of controlled fermented Afiyo - a Nigeria fermented food condiment from Prosopis africana Guill and Perr. Taub. Pakistan J. Nutrit., 6: 620-627.

85. Oguntoyinbo, F. A., Sanni, A.I., Franz, C.M.A.P., and Holzapfel, W.H. (2007): In vitro fermentation studies for selection and evaluation of Bacillus strains as starter cultures for the production of okpehe, a traditional African fermented condiment. Int. J. Food Microbiol.,113: 208-218.

86. Oguntoyinbo, F.A, Huch, M., Cho, G.S., Schillinger, U., Holzapfel, W.H., Sanni, A.I., and Franz, C.M.A.P. (2010): Diversity of Bacillus species isolated from okpehe, a traditional fermented soup condiment from Nigeria. J. Food Protect., 73: 870-878.

87. Okorie, P. C., and Olasupo, N. A. (2013a): Growth and extracellular enzyme production by microorganisms isolated from Ugba-an indigenous Nigerian fermented food. Afr. J. Biotechnol., 12: 4158-4167. doi: 10.5897/AJB11.2842.

88. Omafuvbe, B. O., Falade, O. S., and Osuntogun, B.A. (2004): Chemical and biochemical changes in African Locust Bean Parkia biglobosa, and melon Citrullus vulgaris, seeds during Fermentation to condiments. Pakistan J. Nutrit., 3: $140-145$.

89. Omafuvbe, B.O., Shonukan, O.O., and Abiose, S.H. (2000): Microbiological and biochemical changes in the traditional fermentation of soybean for 'soy-dawadawa' - Nigerian food condiment. Food Microbiol.,17: 469474. 
90. Ongena, M., Jacques, P. (2008): Bacillus lipopeptides: versatile weapons for plant disease biocontrol. Trends in Microbiol., 16(3): 115-125.

91. Oscáriz, J.C., Cintas, L., Holo, H., Lasa, I., Nes, I.F. and Pisabarro, A.G. (2006): Purification and sequencing of cerein 7B, a novel bacteriocin produced by Bacillus cereus Bc7. FEMS Microbiol. Lett., 254: 108-115.

92. Ouoba, L.I.I, Parkouda, C., Diawara, B., Scotti, C., and Varnam, A. H.(2008a): Identification of Bacillus spp. from bikalga, fermented seeds of Hibiscus sabdariffa: phenotypic and genotypic characterization. J. Appl. Microbiol., 104: 122-131. doi: http://dx.doi.org/10.1111/j.1365-2672.2007.03550.

93. Ouoba, L.I.I., Cantor, M.D., Diawara, B., Traore, A.S., and Jakobsen, M. (2003b): Degradation of African Locust Bean oil by Bacillus subtilis and Bacillus pumilus isolated from soumbala, a fermented African Locust Bean condiment. J. Appl. Microbiol., 95: 868-873.

94. Ouoba, L.I.I., Diawara, B., Annan, N.T., Poll, L., and Jakobsen, M. (2005): Volatile compounds of Soumbala, a fermented African locust bean Parkia biglobosa, food condiment. J. Appl. Microbiol., 99: 1413-1421.

95. Ouoba, L.I.I., Diawara, B., Christensen, T., Mikkelsen, J.D., and Jakobsen, M. (2007a): Degradation of polysaccharides and non-digestible oligosaccharides by Bacillus subtilis and Bacillus pumilus isolated from soumbala, a fermented African locust bean Parkia biglobosa, food Condiment. Euro. Food Res. \& Technol., 224: 689-694.

96. Ouoba, L.I.I., Diawara, B., Jespersen, L., and Jakobsen, M. (2007b): Antimicrobial activity of Bacillus subtilis and Bacillus pumilus during the fermentation of African locust bean Parkia biglobosa, for soumbala production. J. Appl. Microbiol.,102: 963-970.

97. Ouoba, L.I.I., Rechinger, K.B., Barkholt, V., Diawara, B., Traore, A.S., and Jakobsen, M. (2003a): Degradation of proteins during the fermentation of African Locust Bean Parkia biglobosa, by strains of Bacillus subtilis and Bacillus pumilus for production of soumbala. J. Appl. Microbiol., 94: 396-402.

98. Ouoba, L.L.I., Diawara, B., moa-Awua, W.K., Traoré, A.S., and Moller, P.L. (2004): Genotyping of starter cultures of Bacillus subtilis and Bacillus pumilus for fermentation of African locust bean Parkia biglobosa, to produce soumbala. Int. J. Food Microbiol., 90: 197-205.

99. Paik S. H., Chakicherla A., and Hansan J.H. (1998): Identification and characterization of the structural and transporter genes for, and the chemical and biological properties of, Sublancin 168, a novel lantibiotic produced by Bacillus subtilis 168. J. Biol. Chem., 273(36): 23134-23142. doi.10.1074/jbc.273.36.23134.

100. Pálffy R., Gardlík R., Behuliak M., Kadasi L., Turna J., and Celec, P. (2009): On the physiology and pathophysiology of antimicrobial peptides. Mol. Med., 15(1-2): 51-59. doi:10.2119/molmed.2008.00087.

101. Parisot, J., Carey, S., Breukink, E., Chan, W.C., Narbad, A., Bonev, B. (2008): Molecular mechanism of target recognition by subtilin, a class I lanthionine antibiotic. Antimicrobial Agents and Chemotherapy., 52: 612-618.

102. Parkouda, C., Nielsen, D.S., Azokpota, P., Ouoba, L.I.I., Amoa-Awua, W.K., Thorsen, L., Hounhouigan, J.D., Jensen, J.H., Tano-Debrah, K., Diawara, B. and Jakobsen, M. (2009): The microbiology of alkaline-fermentation of indigenous seeds used as food condiments in Africa and Asia. Cr. Rev. Microbiol., 35(1): 139-156.

103. Parkouda, C., Thorsen, L., Compaoré, C.S., Nielsen, D.S., Tano-Debrah, K., Jensen, J.S., Diawara, B., Jakobsen, M., (2010): Microorganisms associated with maari, a Baobab seed fermented product. Int. J. Food Microbiol., 142: 292-301.

104. Pathak, K.V., Keharia, H., Gupta, K., Thakur, S. S., and Balaram, P. (2012): Lipopeptides from the banyan endophyte, Bacillus subtilis K1: mass spectrometric characterization of a library of fengycins. J. American Soci. Mass Spec., 23(10): 1716-1728.

105. Pattnaik, P., Grover, S., and Batish, V.K. (2005): Effect of environmental factors on production of lichenin, a chromosomally encoded bacteriocin-like compound produced by Bacillus licheniformis 26L-10/3RA. Microbiol. Res., 160: 213-218.

106. Peypoux, F., Bonmatin, J.M., and Wallach, J. (1999): Recent trends in the biochemistry of surfactin. Appl. Microbiol. Biotechnol. 51(5): 553-563. doi :10.1007/s002530051432.

107. Peypoux, F., Pommier, M.T., Marion, D., Ptak, M., Das, B.C., and Michel, G. (1986): Revised structure of mycosubtilin, a peptidolipid antibiotic from Bacillus subtilis. J. Antibiot., 39(5): 636-641.

108. Ross R.P., Morgan S., and Hill, C. (2002): Preservation and fermentation: past, present and future. Int. J. Food Microbiol., 79(1): 3-16. doi: http://dx.doi.org/10.1016/S0168-1605(02) 00174-5.

109. Sanni, A. I, Onilude, A. A, Fadahunsi, I.F., Ogunbanwo, S.T., and Afolabi, R.O. (2002): Selection of starter cultures for the production of ugba, a fermented soup condiment. Euro. Food Res. \& Technol., 215: 176-180

110. Sanni, A. I., Ayernor, G.S., Sakyi-Dawson, E., and Sefa-Dedeh, S. (2000): Aerobic spore-forming bacteria and chemical composition of some Nigerian fermented soup condiments. Plant Foods for Human Nutrit., 55: 111118 .

111. Sanni, A. I., and Ogbonna, D.N. (1991): The production of owoh - A Nigerian fermented seasoning agent from cotton seed Gossypium Hirsutum L. Food Microbiol., 8: 223-229. 
112. Sarkar, P. K., Hasenack, B., and Nout M. J. R. (2002): Diversity and functionality of Bacillus and related genera isolated from spontaneously fermented soybeans Indian kinema, and locust beans African soumbala. Int. J. Food Microbiol., 77: 175-86.

113. Savadogo, A., Tapi, A., Chollet, M., Wathelet, B., Traoré, A.S., Jacques, P. (2011): Identification of surfactin producing strains in Soumbala and Bikalga fermented condiments using polymerase chain reaction and matrix assisted laser desorption/ ionization-mass spectrometry methods. Int. J. Food Microbiol., 151: 299-306.

114. Schwarzer, D., Finking, R., and Marahiel, M.A. (2003): Non-ribosomal peptides: from genes to products. Nat. Product Rep., 20(3): 275-287. doi: http://dx.doi.org/10.1002/chin.200338264.

115. Sebei, S., Zendo, T., Boudabous, A., Nakayama, J., and Sonomoto, K. (2007): Characterization, N-terminal sequencing and classification of cerein MRX1, a novel bacteriocin purified from a newly isolated bacterium: Bacillus cereus MRX1. J. Appl. Microbiol., 103: 1621-1631.

116. Serizawa, M., Kodama, K., Yamamoto, H., Kobayashi, K., Ogasawara, N., and Sekiguchi, J. (2005): Functional analysis of the YvrGHb two-component system of Bacillus subtilis: identification of the regulated genes by DNA microarray and Northern blot analyses. Biosci. Biotech. Bioch., 69: 2155-2169.

117. Svetoch, E.A., Stern, N.J., Eruslanov, B.V. et al. (2005): Isolation of Bacillus circulans and Paenibacillus polymyxa strains inhibitory to Campylobacter jejuni and characterization of associated bacteriocins. J. Food Protect., 68: 11-17.

118. Seydlová, G., Cabala, R., and Svobodová, J. (2011): Biomedical engineering, trends, research and technologies, in Surfactin-Novel Solutions for Global Issues. In Tech, Rijeka, Croatia.,13: 306-330.

119. Sieber, S.A., and Marahiel, M.A. (2005): Molecular mechanisms underlying non-ribosomal peptide synthesis: approaches to new antibiotics. Chem. Rev., 105(2): 715-738. doi: http://dx.doi.org/10.1021/cr0301191.

120. Siezen, R.J., Kuipers, O.P., and de Von W.M. (1996): Comparison of lantibiotic gene clusters and encoded proteins. Antonie Van Leeuwenhoek., 69: 171-184.

121. Silva, C.C.G., Silva, S.P.M., and Ribeiro S.C. (2018): Application of Bacteriocins and Protective Cultures in Dairy Food Preservation. Front. Microbiol., 9:594. doi: 10.3389/fmicb.2018.00594.

122. Simha B.V., Sood, S., Kumariya, R., and Garsa, A.K. (2012): Simple and rapid purification of pediocin PA-1 from Pediococcus pentosaceous NCDC 273 suitable for industrial application. Microbiol. Res., 167: 544-549. doi: 10.1016/j.micres.2012.01.001.

123. Slepecky, R.A., and Hemphill, H.E. (2006): What is a Bacillus? In: Doi, R.H., McGloghlin, M. Biology of Bacilli: Applications to industry. Butterworth-Heinemann, Boston, MA, pp.1-21.

124. Stein T., Düsterhus, S., Stroh, A., Entian, K.D. (2004): Subtilosin production by two Bacillus subtilis subspecies and variance of the sbo-alb cluster. Appl. Environ. Microbiol., 70: 2349-2353. [PubMed: 15066831].

125. Stein, T. (2005): Bacillus subtilis antibiotics: structures, syntheses and specific functions. Mol. Microbiol., 56(4): 845-857. doi:10.1111/j.1365-2958.2005.04587.

126. Stein, T. (2008): Whole-cell matrix-assisted laser desorption/ionization mass spectrometry for rapid identification of bacteriocin/lantibiotic-producing bacteria. Rap. Commun. Mass Sp., 22: 1146-1152.

127. Stein, T., Borchert, S., Conrad, B., Feesche, J., Hofemeister, B., Hofemeister, J., and Entian, K.D. (2002a): Two different lantibiotic-like peptides originate from the ericin gene cluster of Bacillus subtilis A1/3. J. Bacteriol., 184: 1703-1711.

128. Stein, T., Heinzmann, S., Kiesau, P., Himmel, B., and Entian, K.D. (2003): The spa box for transcriptional activation of subtilin biosynthesis and immunity in Bacillus subtilis. Mol. Microbiol., 47: 1627-1636.

129. Steller, S. et al. (2004): Initiation of surfactin biosynthesis and the role of the SrfD-thioesterase protein. Biochem., 43: 11331-11343.

130. Strieker, M., Tanović, A., and Marahiel, M.A. (2010): Non-ribosomal peptide synthetases: structures and dynamics. Curr. Op. Struct. Biol., 20(2): 234-240. doi: http://dx.doi.org/10.1016/j.sbi.2010.01.009.

131. Sutyak, K. E., Wirawan, R.E., Aroutcheva, A.A., and Chikindas, M.L. (2008b): Isolation of the Bacillus subtilis antimicrobial peptide subtilosin from the dairy product-derived Bacillus amyloliquefaciens. J. Appl. Microbiol., 104(4): 1067-1074. doi:10.1111/j.1365-2672.2007.03626.

132. Taalé, E., Savadogo, A., Zongo, C., Somda, M. K., Sereme, S.S., Karou, S.D., Soulama, I., and Traoré, A.S. (2015). Characterization of Bacillus species producing Bacteriocin-like inhibitory substances (BLIS) isolated from fermented food in Burkina Faso. Int. J. Adv. Res. Biol. Sci. 2(4): 279-290.

133. Tambadou, F. (2014) : Étude de la production de peptides non-ribosomiques chez des souches de Paenibacillus. PhD Thesis, Université de La Rochelle, La Rochelle, 222p.

134. Tapi, A., Chollet-Imbert, M., Scherens, B., and Jacques, P. (2010): New approach for the detection of nonribosomal peptide synthetase genes in Bacillus strains by polymerase chain reaction. Appl. Microbiol. Biotech., 85: 1521-1531.

135. Terlabie, N.N., Sakyi-Dawson, E., Amoa-Awua, W.K., Terlabie, N.N., and Sakyi-Dawson, E., (2006): The comparative ability of four isolates of Bacillus subtilis to ferment soybeans into dawadawa. Int. J. Food Microbiol.,106: 145-152. 
136. Wang, J., Liu, J., Wang, X., Yao, J., and Yu, Z. (2004): Application of electrospray ionization mass spectrometry in rapid typing of fengycin homologues produced by Bacillus subtilis. Lett. Appl. Microbiol., 39: 98-102.

137. Wang, J., and Fung, D.Y.C. (1996): Alkaline-fermented foods: A review with emphasis on pidan fermentation. Crit. Rev. Microbiol., 22: 101-138.

138. Zhang, B., Dong, C., Shang, Q., Han, Y., and Li, P. (2013): New insights into membrane-active action in plasma membrane of fungal hyphae by the lipopeptide antibiotic bacillomycin L. Biochim. Biophy. Acta.,1828(9): 2230-2237.doi: 10.1016/j.bbamem.201305.033.

139. Zheng, G., and Slavik, M.F. (1999): Isolation, partial purification and characterization of a bacteriocin produced by a newly isolated Bacillus subtilis strain. Lett. Appl. Microbiol., 28(5): 363-367. doi:10.1046/j.13652672.1999.00545

140. Zheng, G., Hehn, R., and Zuber, P. (2000): Mutational analysis of the sbo-alb locus of Bacillus subtilis: identification of genes required for subtilosin production and immunity. J. Bacteriol., 182: 3266-3273.

141. Zou, A., Liu, J., Garamus, V.M., Yang, Y., Willumeit, R., and Mu, B. (2010). Micellization activity of the natural lipopeptide [Glu1, Asp5] Surfactin-C15 in aqueous solution. J. Phys. Chem.,114(8): 2712-2718. 